\title{
Article \\ Gibberellins Target Shoot-Root Growth, Morpho-Physiological and Molecular Pathways to Induce Cadmium Tolerance in Vigna radiata $\mathrm{L}$.
}

\author{
Haroon Rashid Hakla ${ }^{1}{ }^{\circledR}$, Shubham Sharma ${ }^{1}\left(\mathbb{D}\right.$, Mohammad Urfan $^{1}$, Narendra Singh Yadav ${ }^{2}{ }^{\circledR}$, Prakriti Rajput ${ }^{1}$, \\ Dinesh Kotwal ${ }^{1} \mathbb{D}$, Arafat Abdel Hamed Abdel Latef ${ }^{3, *(\mathbb{C})}$ and Sikander Pal ${ }^{1, *}$ \\ 1 Plant Physiology Laboratory, Department of Botany, University of Jammu, Jammu 180006, India; \\ haroonhakla@rediffmail.com (H.R.H.); shubhamsharma199425@gmail.com (S.S.); \\ urfanbutt1992@gmail.com (M.U.); prakritirajput2512@gmail.com (P.R.); dskotwal7@gmail.com (D.K.) \\ 2 Department of Biological Sciences, University of Lethbridge, Lethbridge, AB 403587, Canada; \\ narendra.yadav@uleth.ca \\ 3 Department of Biology, Turabah University College, Turabah Branch, Taif University, P.O. Box 11099, \\ Taif 21944, Saudi Arabia \\ * Correspondence: a.moawd@tu.edu.sa or moawad76@gmail.com (A.A.H.A.L.); \\ sikanderpal@jammuuniversity.ac.in (S.P.)
}

check for

updates

Citation: Hakla, H.R.; Sharma, S.; Urfan, M.; Yadav, N.S.; Rajput, P.;

Kotwal, D.; Abdel Latef, A.A.H.; Pal, S. Gibberellins Target Shoot-Root Growth, Morpho-Physiological and Molecular Pathways to Induce Cadmium Tolerance in Vigna radiata $\mathrm{L}$. Agronomy 2021, 11, 896. https:// doi.org/10.3390/agronomy11050896

Academic Editor: Charles T. Hunter

Received: 3 April 2021

Accepted: 29 April 2021

Published: 2 May 2021

Publisher's Note: MDPI stays neutral with regard to jurisdictional claims in published maps and institutional affiliations.

Copyright: (c) 2021 by the authors. Licensee MDPI, Basel, Switzerland. This article is an open access article distributed under the terms and conditions of the Creative Commons Attribution (CC BY) license (https:/ / creativecommons.org/licenses/by/ $4.0 /)$.

\begin{abstract}
Cadmium (Cd) inhibits plant growth, perturbs nutrient uptake, and affects chloroplast ultrastructure. The role of $\mathrm{Cd}$ stress in affecting growth and physiology and ameliorative effects of gibberellins (GAs) in Cd-induced toxicity in mung bean are lesser-known. This study comprehensively investigated $\mathrm{Cd}$ stress $\left(\mathrm{CdCl}_{2}, \mathrm{IC}_{50}-500 \mu \mathrm{M} \mathrm{L}^{-1}\right)$ with or without $\mathrm{GA}_{3}$ on mung bean (Vigna radiata L. Var. SML-668). In our methodology, a total of 80 mung bean plants (15 days old of uniform height) were divided into four groups, and each group ( $n=20)$ was subjected to four different treatments (Control, $\mathrm{CdCl}_{2}, \mathrm{GA}_{3}, \mathrm{CdCl}_{2}+\mathrm{GA}_{3}$ ) twice during the entire life cycle of mung bean plants (until harvest 85-90 days). Results revealed negative impacts of Cd stress on shoot morphometry (plant height, leaf surface area, stem diameter, shoot fresh weight, number of leaves, number of pods, length, and diameter of pods), root morphometry (root length, root surface area, root dry weight, nodule number and nodule diameter), photosynthetic pigments, and agronomic traits. $\mathrm{GA}_{3}$ application ameliorated $\mathrm{Cd}$ stress by modulating shoot and root growth, improving overall plant metabolism, photosynthetic pigments, and shoot and root morphometry and transcript abundance of VrPCS1, VrIRT1, VrIRT2 and VrCD29. Thus, we propose $\mathrm{GA}_{3}$ application for the effective management of Cd-induced phytotoxicity in mung bean plants.
\end{abstract}

Keywords: cadmium stress; Vigna radiata; gibberellic acid; root morphometry; root nodules; pod number

\section{Introduction}

Heavy metal (HM) contamination of the biosphere has increased sharply for the last few years and poses major concerns for the environment and human health worldwide. Metals, such as cadmium $(\mathrm{Cd})$, copper $(\mathrm{Cu})$, lead $(\mathrm{Pb})$, and chromium $(\mathrm{Cr})$, could appear in natural and agricultural areas and water bodies. Latest modeling approaches showed mean bioaccumulation factors of heavy metals follow the order $\mathrm{Cd}>\mathrm{Zn}>\mathrm{As}>\mathrm{Cu}>\mathrm{Ni}$ $>\mathrm{Hg}>\mathrm{Cr}>\mathrm{Pb}$ in large number of crops [1]. Among $\mathrm{HMs}, \mathrm{Cd}$ pollution poses a serious threat to soil quality and human health upon consuming Cd polluted edible crops [2,3]. Hazardously, $\mathrm{Cd}$ toxicity is much higher than other organic toxic compounds, due to its greater mobility $[4,5]$. Cd is hardly degraded in soil, leading to biomagnifications in soil and plants growing in $\mathrm{Cd}$ polluted soils. In general, $\mathrm{Cd}$ is not a necessary element for plant growth and its excess has a series of harmful effects, including inhibition of plant growth, perturbed nutrient uptake, and chloroplast ultrastructure [4-7].Cd generates oxidative 
stress in plants via inducing the production of reactive oxygen species (ROS), such as superoxide anion radicals $\left(\mathrm{O}_{2}{ }^{-}\right)$, hydroxyl radicals, and hydrogen peroxide $\left(\mathrm{H}_{2} \mathrm{O}_{2}\right)[8,9]$.

Vigna radiata $\mathrm{L}$. (mung bean) is a widely grown pulse crop in Asia. It is an economical source of protein for direct human consumption [1]. Mung bean is affected by drought [10,11], salinity [12], and other abiotic [13] and biotic stresses [14]. Mung bean plants suffer significantly from HM pollution also in the agricultural soils polluted from effluents of adjoining industrial areas [4-7]. Reduction in plant growth and pod size occurs under HM stress in mung bean [15-17]. Several biotechnological strategies have been adopted towards improving the HM stress management in crop plants [18], such as HM tolerance assisted by microbes [19], transgenics [20,21], and use of phytohormones [22,23]. A strong criticism for transgenic approaches of improving yield and abiotic or biotic stress tolerances of crop plants have impeded the acceptance of transgenic crops by the population world over $[24,25]$. Eco-friendly approaches (phytohormonal and microbe assisted) of improving HM stress tolerances in crops offers an alternate way without fiddling the genetic make of crop plants and germplasm erosion [26,27]. Literature survey showed scant information about the holistic impact of $\mathrm{Cd}$ stress on morphometrical, reproductive, physiological, and agronomical attributes on mung bean plants. Gibberellins (GAs) are important plant hormones implicated in several developmental and physiological processes in plants. GAs role in heavy metal stress management in plants is widely accepted. However, GAs role in reducing Cd-associated stress in mung bean plants is least explored and mostly confined to photosynthesis [28] and seedlings stages [29]. Thus, this study comprehensively investigated the effects of $\mathrm{Cd}$ stress on the mung bean plants and the role of gibberellic acid ( $\mathrm{GA}_{3}-$ a type of gibberellins) in mitigating Cd-induced stress markers. Keeping the current understanding of $\mathrm{Cd}$ stress in mung bean plants, this study was carried out to observe the impact of $\mathrm{Cd}$ stress on growth, as well as biochemical parameters of plants of $V$. radiata from seedling to fruiting stage in the presence of $500 \mu \mathrm{M} / \mathrm{L} \mathrm{GA}_{3}$ concentration and to provide a theoretical basis for the risk assessment of heavy metal pollution and the maintenance of sustainable agricultural production.

\section{Materials and Methods}

Experiment 1: Growth of Young Plants in Hydroponics

Certified seeds of Vigna radiata L. (var. SML-668) were procured from the Agriculture station, Jammu, India. To determine the impact of Cd stress on establishing root and shoot system in young plants, uniform seedlings raised for five days by paper roll method on plain water (control), were subjected to four different treatment regimes viz. Control, $\mathrm{CdCl}_{2}$, $\mathrm{GA}_{3}$ and $\mathrm{CdCl}_{2}+\mathrm{GA}_{3}$ for 10 days. Young plants were harvested separately into shoot, root, and emerging leaves to measure root and shoot length, and number of emerging leaves and cotyledonary leaves.

\section{Experiment 2: Growth of Plants in Soil}

Experiments were conducted in the poly house $\left(32.72^{\circ} \mathrm{N} 74.85^{\circ} \mathrm{E}\right)$ of the Department of Botany, University of Jammu, India. Certified seeds of Vigna radiata L. (var. SML-668) were sown in the field beds, at a uniform distance during September 2018 and 2019. At 10 days after sowing (DAS), uniform healthy seedlings were selected and transplanted to pots ( $26 \mathrm{~cm}$ height and $25 \mathrm{~cm}$ diameter) filled with $5 \mathrm{~kg}$ garden soil mixed with farmyard manure in the ratio of 3:1. A total of 80 mung bean plants (15 days old of uniform height) were divided into four groups, with each group $(n=20)$ subjected to four different treatments (Control, $\mathrm{CdCl}_{2}, \mathrm{GA}_{3}, \mathrm{CdCl}_{2}+\mathrm{GA}_{3}$ ), for the next 45 days with and without treatment of $\mathrm{GA}_{3}(500 \mu \mathrm{M} / \mathrm{L})$ by soil drench method. Water was applied through surface irrigation at the three days interval based on the calculated evapotranspiration demand following the FAO-Penman Monteith model as described elsewhere [30]. Plants were then thoroughly investigated for changes in morphometrical, physiological parameters, and molecular pathways. Prior to $\mathrm{CdCl}_{2}$ application, $\mathrm{IC}_{50}$ was calculated for mung bean seedlings grown in Petri dishes over five days. 


\subsection{Shoot and Root Morphometry and Biomass}

The number of cotyledonary and emerging leaves, seedling shoot length (SSL), seedling shoot biomass (SSB), seedling root biomass (SRB), and total root length (TRL), lateral root number (LRN), and TRL/R was measured for young plants grown in hydroponics system using paper roll method. Young root images were analyzed by freely available Image J software Version $1.52 \mathrm{v}$.

For mature plants grown in soil, shoot height $(\mathrm{cm})$, stem thickness $(\mathrm{cm})$, leaf number $(\mathrm{N})$, and leaf surface area $\left(\mathrm{cm}^{2}\right)$ were measured on a weekly basis. Fresh and dry weights of leaves, stem, and roots were measured at the time of harvest [31]. Root length, root surface area, nodule number, and nodule diameter was measured at the harvesting stage. Root growth was imaged using a high-resolution camera (Nikon B500 Camera, New Delhi, India).

\subsection{Histological Localization and Estimation of Cd Accumulation by Atomic Absorption Spectrometry}

Histological localization of $\mathrm{Cd}^{2+}$ ions was performed with $0.5 \mathrm{M}$ oxalic acid and visualized as white crystalline precipitates. Thin transverse sections of the stem were dipped for $10 \mathrm{~min}$ in a solution of $0.5 \mathrm{M}$ Oxalic acid at room temperature. The sections were imaged using a high-resolution camera (Nikon B500 Camera, New Delhi, India). For the measurement of $\mathrm{Cd}$ content in mature plants, atomic absorption spectrometry (AAS, Shimazdu, Tokyo, Japan) was used [32].

\subsection{Biochemical Estimations and Stress Indices}

About $500 \mathrm{mg}$ of fresh leaves were homogenized with ethanol (95\%) $(5 \mathrm{~mL})$ to make a slurry, samples were centrifuged at 13,000 rpm for $10 \mathrm{~min}$, and estimation of $\mathrm{Chl} a, \mathrm{Chl} b$, and carotenoids (CAR) [33], sucrose content (a major photosynthate) [34] were carried. Protein estimation, ascorbic acid (ASA), and total phenols (TP) were performed as described [35]. Nodule leg hemoglobin content and Urease enzyme (EC 3.5.1.5) activity was measured by the Berthelot method [36] in the root nodules. Estimation of stress indices such as proline (PL) and malondialdehyde (MDA) was performed as described in Choudhary et al. [37].

\subsection{Agronomic Traits}

Economically important traits of mung bean plants such as pod diameter, pod length, pod fresh weight, pod dry weight, seed number/ten pods, 100 seeds weight, seeds weight/pod, seed SA, seed diameter, seed protein, and seed sugar content were measured at the harvesting stage using appropriate standard procedures as described elsewhere [38]. Seed attributes particularly, width, length, thickness, surface area, Ew, Ev, geometric mean $(\mathrm{Dg})$, seed shape $(\Phi \%)$, volume of the grain $(\mathrm{V})$, percent seed germination $(\% \mathrm{G})$, and seed protein content (SPr) and seed total phenol content (STPC), were measured.

\subsection{Quantitative PCR Analysis}

Total RNA was extracted from frozen root samples using TriZol (Thermofisher, Waltham, MA, USA) with DNase treatment according to the manufacturer's instruction. One microgram of RNA was reverse transcribed using cDNA Synthesis Kit (Thermofisher, Waltham, MA, USA) with oligodT as primers. Quantitative polymerase chain reaction (qPCR) analysis was conducted on QuantStudio ${ }^{\mathrm{TM}} 3$ Real-Time PCR System (Applied Biosystems, Foster City, CA, USA), and the amplification curve was checked with software provided. The reaction included a SYBR green PCR master mix (Thermofisher, Waltham, MA, USA) with 4-folds diluted cDNA in the total volume of $20 \mu \mathrm{L}$ [35]. A comparative delta $\mathrm{Ct}\left(2^{-\Delta \mathrm{Ct}}\right)$ method was used to quantify the relative expression of Vigna radiata phytochelatin synthase 1 (VrPCS1), VrIron transporter 1 (VrIRT1), VrIron transporter 2 (VrIRT2) and $\mathrm{Vr}$ cadmium response $(\operatorname{VrCDR} 29)$ with actin as endogenous control. Primer sequences are provided in [39]. 


\subsection{Pearson Correlation Analyses}

A pair-wise correlation between $\mathrm{Cd}$ stress with or without $\mathrm{GA}_{3}$ on plant fitness and agronomic attributes was carried out. Pearson's correlation coefficient $(r)$ was calculated using IBM SPSS 20.0 for ten traits (shoot height, stem thickness, leaf number, leaf surface area, root length) of plant fitness and agronomic importance (seed number, seed weight, seed weight/pod and seed surface area). A linear correlation coefficient $(r)$ was calculated to understand the interaction of two factors at a time at $p<0.05$ and $p<0.01$ with a number of biological replicates $(n=20)$ for the following combination of treatments $\mathrm{CN}$ versus $\mathrm{Cd}$, $\mathrm{Cd}$ versus $\mathrm{Cd}+\mathrm{GA}_{3}$ and $\mathrm{CN}$ versus $\mathrm{Cd}+\mathrm{GA}_{3}$. The $r$ values fall in the range of +1 to -1 , with positive values indicating a positive linear relationship among two treatments and -ve value indicating the negative relationship among treatments.

\subsection{Statistical Analysis}

Experiments were arranged in a randomized factorial design (2018 and 2019). Data obtained were analyzed by ANOVA and all means were separated at the $p<0.05$ level using the Duncan test. All calculations and data analyses were performed using the IBM SPSS 20.0 for Windows software package, and the values were expressed by means and standard error (SE).

\section{Results}

\subsection{Growth of Young Shoot-Root System under Cd Stress and after $G A_{3}$ Application}

The establishment of the young root system, cotyledonary leaves, and emergence of young leaves were affected under $\mathrm{Cd}$ stress. The development of cotyledonary leaves is a prerequisite for establishing a healthy young plant. Cd stressed plants showed $13 \%$ and $74 \%$ reductions in establishment of cotyledonary leaves and the emergence of young leaves compared to control plants (Figure 1a). $\mathrm{GA}_{3}$ applied to $\mathrm{Cd}$ stressed plants showed improvement in establishment and emergence of cotyledonary leaves and young leaves by $15 \%$ and $17 \%$, respectively, compared to $\mathrm{Cd}$ alone treated plants. $\mathrm{GA}_{3}$ alone showed no signficant reduction in the emergence of young leaves over control (Figure 1a). Seedling shoot length (SSL) reduced by $13 \%$ in Cd stressed plants over control. While $\mathrm{GA}_{3}$ could improve SSL by $20 \%$ in Cd stressed plants compared to only Cd-treated plants. About $17 \%$ increase in SSL was noted in $\mathrm{GA}_{3}$ alone treated plants compared to control (Figure $1 \mathrm{~b}$ ). Seedling shoot biomass (SSB) and seedling root biomass (SRB) were reduced by $15 \%$ and $29 \%$ in Cd stressed plants over control. GA $_{3}$ improved SSB and SRB by $22 \%$ and $21 \%$, respectively, in $\mathrm{Cd}$ stressed plants compared to only Cd-treated plants. No significant change in SSB and SRB occurred in $\mathrm{GA}_{3}$ alone treated plants over control plants (Figure 1c).

For root growth, Cd stressed plants showed significant impact on establishing the young root system, such that $41 \%, 26 \%$, and $54 \%$ reductions in total root length (TRL), lateral roots number (LRN), and total root length/ roots (TL/R) were recorded in $\mathrm{Cd}$ stressed plants over control. $\mathrm{GA}_{3}$ in Cd stressed plants showed improvements in TRL and $\mathrm{TL} / \mathrm{R}$ over $\mathrm{Cd}$ alone treated plants. $\mathrm{GA}_{3}$ alone brought reductions in TRL, LRN, and TL/R by $16 \%, 22 \%$, and $17 \%$ compared to control plants (Figure $1 \mathrm{~d}, \mathrm{e}$ ).

\subsection{Shoot Morphometery under Cd Stress and after GA3 Application in Pot Experiments}

A consistent decrease in stem height and stem diameter was noted in Cd-treated plants (Figure 2a,b), with maximum reductions at 80 DAS. GA 3 steadily improved stem height and stem diameter in Cd-treated plants, with a maximum increase recorded at 70 DAS over Cd-treated plants (Figure $2 \mathrm{a}, \mathrm{b}$ ). $\mathrm{GA}_{3}$ alone improved stem height significantly at 50-80 DAS and while stem diameter in a non significant manner over control plants. A constant decrease in leaf number was noted in Cd-treated plants; with a maximum reduction at 70 and 80 DAS compared to controls (Figure 2c). $\mathrm{GA}_{3}$ application to $\mathrm{Cd}$ treated plants could ameliorate negative $\mathrm{Cd}$ impact on leaf number, with most significant increases at 70 and 80 DAS over Cd alone treated plants. No significant change in leaf number was recorded for. 


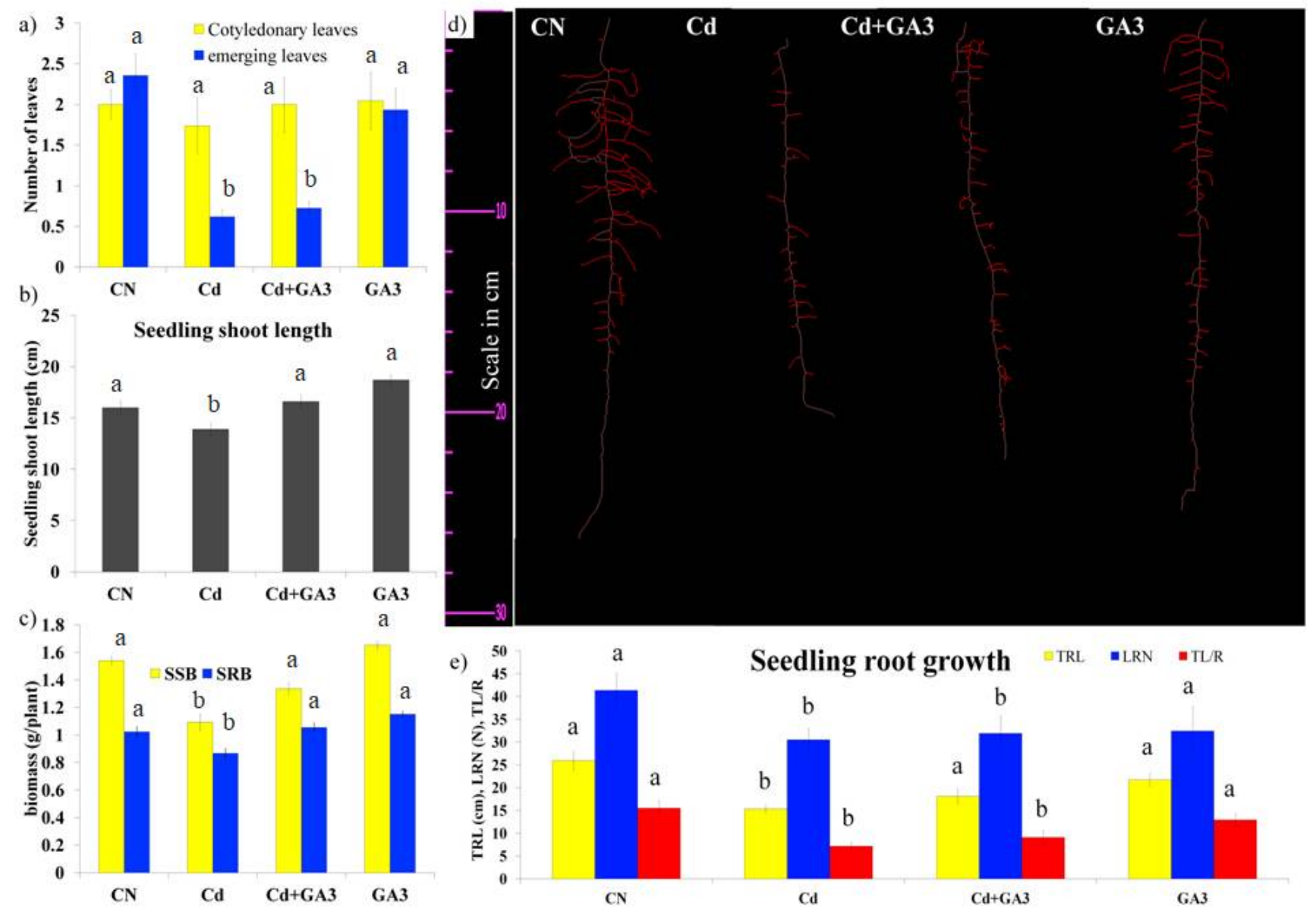

Figure 1. Effect of $\mathrm{GA}_{3}$ on the growth of young mung bean plants under cadmium (Cd) stress in hydroponics.Effect of $\mathrm{GA}_{3}$ with or without cadmium (Cd) stress on the number of cotyledonary and young emerging leaves (a), seedling shoot length (b), seedling shoot biomass (SSB) and seedling root biomass (SRB) (c), length of the root system (d), total root length (TRL), lateral root number (LRN), and total lateral roots (TLR)/R (e) in paper roll method grown under control $(\mathrm{CN})$, cadmium $(\mathrm{Cd})$ stress, $\mathrm{Cd}+$ gibberellins $\left(\mathrm{GA}_{3}\right)$, and $\mathrm{GA}_{3}$ alone conditions hydroponically. Data presented are means \pm standard errors ( $n=10$, biological replicates). Different letters $(a, b)$ indicate significant differences from control in all combinations (Tukey's test, $p \leq 0.05$ ).

$\mathrm{GA}_{3}$ alone except at 80 DAS (Figure 2c). At all observation points, leaf surface area (LSA) was reduced in Cd-treated plants, with maximum reduction recorded at 60,70 and 80 DAS over control plants. GA $_{3}$ improved LSA in Cd-treated plants non significantly at over Cd-treated plants at all observation points (Figure 2d). Similarly, increased LSA was recorded in $\mathrm{GA}_{3}$ alone treated plants over control plants (Figure 2d).

\subsection{Effect of $\mathrm{GA}_{3}$ on Root Surface Area and Root Nodules Attributes under Cd Stress in Pot Experiments}

Root length (RL) and root surface area (RSA) play an important role in the absorption of water and uptake of minerals from the soil solution. In the current study, Cd stressed plants showed significant reductions in RL and RSA over control plants. Furthermore, $\mathrm{GA}_{3}$ applied to $\mathrm{Cd}$ stressed plants increased RSA significantly over Cd stressed plants (Figure 2e,f). No significant change in RSA under $\mathrm{GA}_{3}$ alone was observed compared to control plants (Figure 2e,f). 

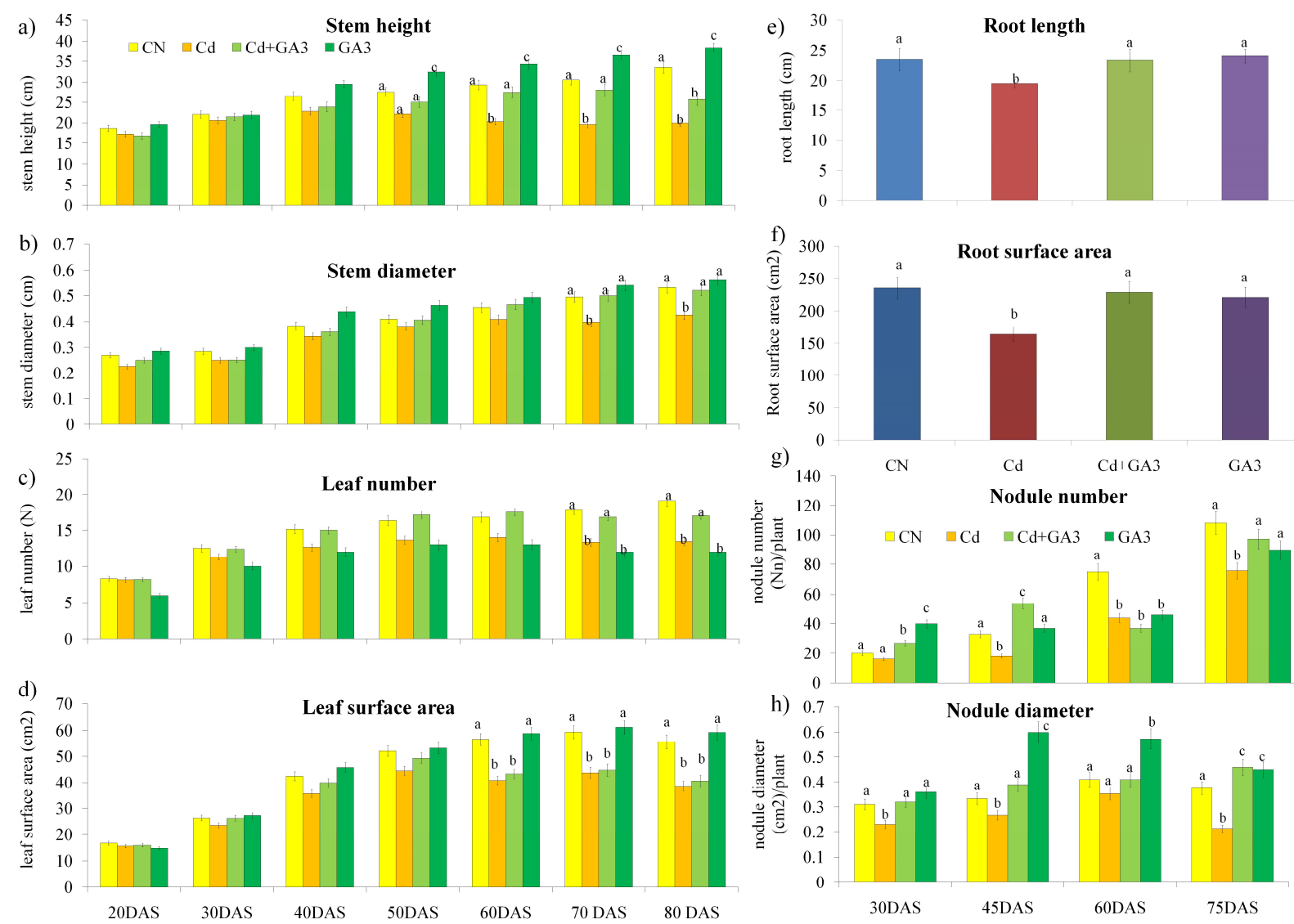

Figure 2. Effect of $\mathrm{GA}_{3}$ on the growth parameters of mung bean plants under cadmium (Cd) stress in soil. Effect of $\mathrm{GA}_{3}$ with or without cadmium $(\mathrm{Cd})$ stress on stem height $(\mathrm{cm})(\mathbf{a})$, stem diameter $(\mathrm{cm})(\mathbf{b})$, leaf number $(N)(\mathbf{c})$, leaf surface area $\left(\mathrm{cm}^{2}\right)(\mathbf{d})$, root length $(\mathrm{cm})(\mathbf{e})$, root surface area $\left(\mathrm{cm}^{2}\right)(\mathbf{f})$, nodule number $(\mathrm{g})$, nodule diameter $(\mathrm{cm})(\mathbf{h})$ of mung bean plants grown in soil in pots at 20 days after sowing (DAS), 30 DAS, 40 DAS, 50 DAS, 60 DAS, 70 DAS, and 80 DAS for (a-d) and 30 DAS, 45 DAS, 60 DAS, and 75 DAS for (e-h) grown under control (CN), cadmium (Cd) stress, Cd+ gibberellins $\left(\mathrm{GA}_{3}\right)$, and $\mathrm{GA}_{3}$ alone conditions. Data presented are means \pm standard errors $(n=10$, biological replicates). Different letters $(a, b, c)$ indicate significant differences from control in all combinations (Tukey's test, $p \leq 0.05$ ).

Root nodule number (RNN) in Cd stressed plants decreased at all the observation points $(30,45,60$, and $75 \mathrm{DAS})$ over control. $\mathrm{GA}_{3}$ improved RNN in Cd-treated plants at 30, 45 and 75 DAS, while declined it at 60 DAS compared to Cd stressed plants (Figure 2g). $\mathrm{GA}_{3}$ alone enhanced RNN at $30 \mathrm{DAS}$, while reduced RNN at 45,60 and 75 DAS over control (Figure 2g). Root nodule diameter (RND) showed a consistent decline in Cd stressed plants, with a maximum reduction (43\%) noted at 75 DAS over control (Figure $2 \mathrm{~h}$ ). GA 3 improved RND in Cd stressed plants significantly at 30, 45 and 75 DAS over Cd stressed plants. RND also improved in $\mathrm{GA}_{3}$ alone treated plants, with a increase observed at 45, 60 and 75 DAS over control plants (Figure 2h).

Urease activity in root nodules decreased under Cd stress at 30, 45, and $60 \mathrm{DAS}$, while a nonsignificant increase in activity at 75 DAS occurred compared to control. GA 3 could improve urease activity consistently in Cd stressed plants over Cd-treated plants (Table 1). $\mathrm{GA}_{3}$ alone could improve urease activity at 45 and 60 DAS compared to control. A consistent reduction in legHb content was recorded in nodules of $\mathrm{Cd}$ stressed plants at all observation points $(30,60$, and 75 DAS), with a maximum decline $57 \%$ noted at 60 DAS over control. $\mathrm{GA}_{3}$ could improve legHb contents in Cd-treated plants at all the observation points, with a maximum increase of $253 \%$ recorded for 60 DAS over Cd stressed plants (Table 1). Furthermore, $\mathrm{GA}_{3}$ alone reduced leg $\mathrm{Hb}$ content at 30 and $40 \mathrm{DAS}$, while increased it at 60 and 75 DAS compared to control (Table 1). 


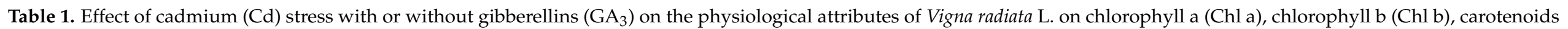

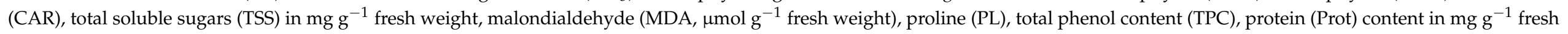

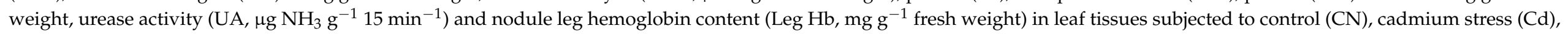
gibberellins $\left(\mathrm{GA}_{3}\right), \mathrm{Cd}+\mathrm{GA}_{3}$ at 30 days after sowing (DAS), 45 DAS, 60 DAS, and 75 DAS.

\begin{tabular}{|c|c|c|c|c|c|c|c|c|c|c|c|}
\hline & & Chla & Chlb & CAR & TSS & MDA & PL & TPC & Prot & $\begin{array}{c}\text { Urease } \\
\text { Activity }\end{array}$ & Leg $\mathrm{Hb}$ \\
\hline \multirow{3}{*}{$\mathrm{CN}$} & $30 D A S$ & $4.98 \pm 0.29 \mathrm{a}$ & $1.03 \pm 0.06 \mathrm{a}$ & $1.02 \pm 0.06 \mathrm{a}$ & $9.2 \pm 0.55 \mathrm{a}$ & $0.63 \pm 0.03 \mathrm{a}$ & $2.83 \pm 0.14 \mathrm{a}$ & $1.65 \pm 0.08 \mathrm{a}$ & $1.36 \pm 0.06 \mathrm{a}$ & $7.22 \pm 0.36 \mathrm{a}$ & $1.26 \pm 0.29 a$ \\
\hline & $45 D A S$ & $6.21 \pm 0.37 \mathrm{a}$ & $1.38 \pm 0.08 \mathrm{a}$ & $1.96 \pm 0.11 \mathrm{a}$ & $12.51 \pm 0.75$ & $1.23 \pm 0.06 \mathrm{a}$ & $3.56 \pm 0.17 \mathrm{a}$ & $2.56 \pm 0.12 \mathrm{a}$ & $1.59 \pm 0.07 \mathrm{a}$ & $8.60 \pm 0.43 a$ & $2.54 \pm 0.08$ \\
\hline & 75DAS & $6.42 \pm 0.38 \mathrm{a}$ & $3.41 \pm 0.20 \mathrm{a}$ & $1.75 \pm 0.10 \mathrm{a}$ & $20.36 \pm 1.22$ & $1.88 \pm 0.09 \mathrm{a}$ & $6.56 \pm 0.32 \mathrm{a}$ & $4.56 \pm 0.22 \mathrm{a}$ & $3.20 \pm 0.16 \mathrm{a}$ & $4.02 \pm 0.20 \mathrm{a}$ & $6.09 \pm 0.19 \mathrm{~b}$ \\
\hline \multirow{4}{*}{$\mathrm{Cd}$} & $30 D A S$ & $2.25 \pm 0.13 b$ & $2.63 \pm 0.15 b$ & $1.62 \pm 0.09 \mathrm{~b}$ & $5.2 \pm 0.31$ & $0.85 \pm 0.04 \mathrm{~b}$ & $8.56 \pm 0.42 b$ & $1.99 \pm 0.09 \mathrm{a}$ & $3.58 \pm 0.17 b$ & $6.74 \pm 0.33 a$ & $0.79 \pm 0.03$ \\
\hline & $45 D A S$ & $3.55 \pm 0.21 b$ & $2.28 \pm 0.13 b$ & $2.02 \pm 0.12 \mathrm{a}$ & $7.26 \pm 0.43$ & $1.65 \pm 0.08 \mathrm{~b}$ & $10.56 \pm 0.52 b$ & $2.56 \pm 0.12 a$ & $2.15 \pm 0.10 b$ & $5.47 \pm 0.27 b$ & $2.69 \pm 0.17 b$ \\
\hline & $60 D A S$ & $3.42 \pm 0.20 b$ & $4.58 \pm 0.27 b$ & $2.59 \pm 0.15 b$ & $9.42 \pm 0.56$ & $2.88 \pm 0.14 b$ & $17.23 \pm 0.86 b$ & $4.56 \pm 0.22 \mathrm{~b}$ & $3.22 \pm 0.16 b$ & $4.91 \pm 0.24 b$ & $2.14 \pm 0.04 \mathrm{~b}$ \\
\hline & $75 D A S$ & $3.81 \pm 0.22 b$ & $3.58 \pm 0.21 \mathrm{a}$ & $1.75 \pm 0.10 \mathrm{a}$ & $11.96 \pm 0.71$ & $3.01 \pm 0.15 b$ & $19.36 \pm 0.96 b$ & $5.66 \pm 0.28 \mathrm{a}$ & $3.06 \pm 0.15 \mathrm{a}$ & $4.52 \pm 0.22 \mathrm{a}$ & $2.77 \pm 0.29 \mathrm{~b}$ \\
\hline \multirow{4}{*}{$\mathrm{Cd}+\mathrm{GA}_{3}$} & $30 D A S$ & $3.94 \pm 0.23 c$ & $4.00 \pm 0.24 \mathrm{c}$ & $1.63 \pm 0.09$ & $5.6 \pm 0.33 b$ & $0.72 \pm 0.03 \mathrm{a}$ & $15.23 \pm 0.76 \mathrm{~d}$ & $1.89 \pm 0.09 b$ & $1.42 \pm 0.07 \mathrm{a}$ & $10.01 \pm 0.5 b$ & $0.91 \pm 0.03$ \\
\hline & $45 D A S$ & $3.97 \pm 0.23 b$ & $3.41 \pm 0.20 c$ & $2.84 \pm 0.17 b$ & $8.50 \pm 0.51$ & $1.35 \pm 0.06 \mathrm{a}$ & $19.65 \pm 0.98 \mathrm{~d}$ & $2.44 \pm 0.12 \mathrm{a}$ & $2.45 \pm 0.12 b$ & $9.54 \pm 0.47 \mathrm{a}$ & $2.68 \pm 0.08 \mathrm{~b}$ \\
\hline & $60 D A S$ & $4.25 \pm 0.25 b$ & $3.51 \pm 0.21 c$ & $3.17 \pm 0.19 c$ & $18.93 \pm 1.13$ & $2.14 \pm 0.10 c$ & $20.12 \pm 1.00 b$ & $3.66 \pm 0.18 \mathrm{a}$ & $3.77 \pm 0.18 c$ & $9.35 \pm 0.46 c$ & $6.04 \pm 0.58$ \\
\hline & $75 D A S$ & $4.26 \pm 0.25 \mathrm{~d}$ & $4.09 \pm 0.24 \mathrm{c}$ & $2.90 \pm 0.17 b$ & $21.67 \pm 1.3$ & $2.04 \pm 0.10 \mathrm{a}$ & $21.36 \pm 1.06 \mathrm{~b}$ & $4.33 \pm 0.21 \mathrm{a}$ & $2.70 \pm 0.13 b$ & $5.12 \pm 0.25 c$ & $8.16 \pm 0.42 c$ \\
\hline \multirow{4}{*}{$\mathrm{GA}_{3}$} & $30 D A S$ & $5.90 \pm 0.35 \mathrm{a}$ & $2.67 \pm 0.16 b$ & $3.39 \pm 0.20$ & $8.7 \pm 0.52 c$ & $0.84 \pm 0.04 b$ & $4.56 \pm 0.22 c$ & $2.15 \pm 0.10 b$ & $1.78 \pm 0.08 \mathrm{a}$ & $7.97 \pm 0.39 \mathrm{a}$ & $1.02 \pm 0.04 \mathrm{a}$ \\
\hline & $45 D A S$ & $6.44 \pm 0.38 a$ & $3.30 \pm 0.19 b$ & $2.49 \pm 0.14 b$ & $11.55 \pm 0.69$ & $1.65 \pm 0.08 \mathrm{~b}$ & $5.60 \pm 0.28 c$ & $2.66 \pm 0.13 a$ & $2.19 \pm 0.10 b$ & $7.52 \pm 0.37 \mathrm{a}$ & $4.02 \pm 0.29 b$ \\
\hline & 60DAS & $7.25 \pm 0.43 a$ & $2.62 \pm 0.15 c$ & $2.37 \pm 0.14 \mathrm{a}$ & $26.6 \pm 1.59$ & $2.00 \pm 0.10 \mathrm{a}$ & $12.56 \pm 0.62 c$ & $3.36 \pm 0.16 a$ & $3.63 \pm 0.18 b$ & $7.66 \pm 0.38 a$ & $5.42 \pm 0.15$ \\
\hline & 75DAS & $7.72 \pm 0.46 c$ & $5.73 \pm 0.34 b$ & $1.88 \pm 0.11 b$ & $31.24 \pm 1.87$ & $2.15 \pm 0.10 \mathrm{a}$ & $16.23 \pm 0.81 b$ & $4.56 \pm 0.22 \mathrm{a}$ & $3.56 \pm 0.17 \mathrm{a}$ & $7.85 \pm 0.39 b$ & $4.58 \pm 0.16 \mathrm{~b}$ \\
\hline
\end{tabular}

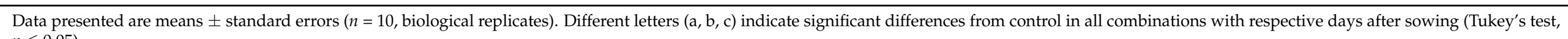
$p \leq 0.05)$. 


\subsection{Effect of $\mathrm{GA}_{3}$ on Plant Biomass under Cd Stress}

Plant biomass is a good indicator of plant fitness under abiotic stress. In the present study, Cd stressed plants showed $49 \%$ reduction in fresh leaf biomass (FLB) and $29 \%$ in dry leaf biomass (DLB) compared to control (Figure $3 a, b$ ). GA 3 could improve FLB and DLB by $24 \%$ and $63 \%$ in Cd stressed plants over Cd-treated plants alone (Figure $3 a, b)$. GA $_{3}$ alone improved FLB and DLB compared to control plants. Stem fresh (SFB) and stem dry biomass (SDB) showed a reduction by $12 \%$ and $11 \%$ in Cd stressed plants over control. $\mathrm{GA}_{3}$ supplementation to $\mathrm{Cd}$ stressed plants witnessed increased SFB $(8 \%)$ and SDB $(9 \%)$ compared to $\mathrm{Cd}$ alone treated plants (Figure $3 \mathrm{c}, \mathrm{d}) . \mathrm{GA}_{3}$ alone could improve SFB $(11 \%)$ and SDB (12\%) over untreated control plants. Root biomass is a key determinant for the successful survival of a plant under abiotic stresses (Figure 3e,f). Under Cd stress, $14 \%$ and $50 \%$ reduction in root fresh biomass (RFB) and root dry biomass (RDB) was noted over control. $\mathrm{GA}_{3}$ could improve both RFB and RDB by $6 \%$ and $35 \%$ in Cd stressed plants over Cd-treated plants. $\mathrm{GA}_{3}$ alone reduced RFB and RDB over control plants (Figure 3e,f).

a)

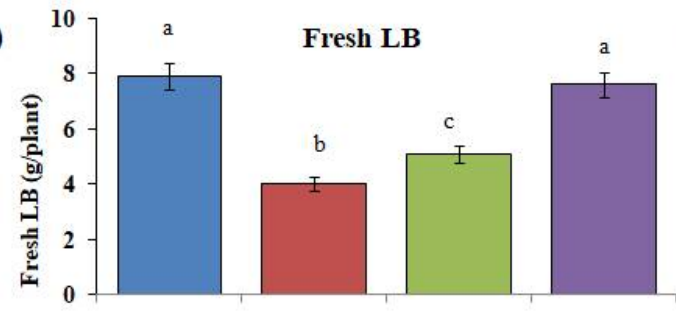

b)

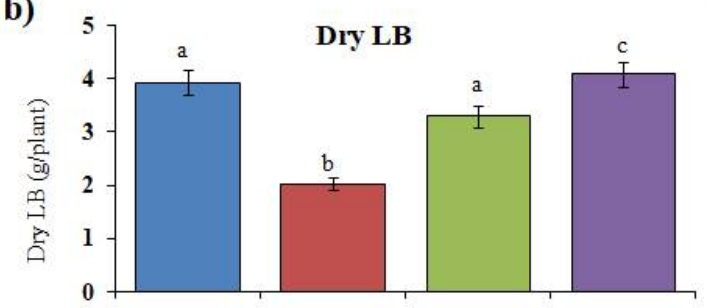

c)

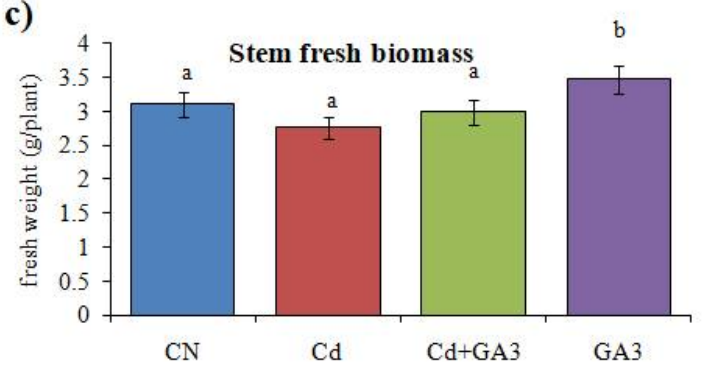

d)

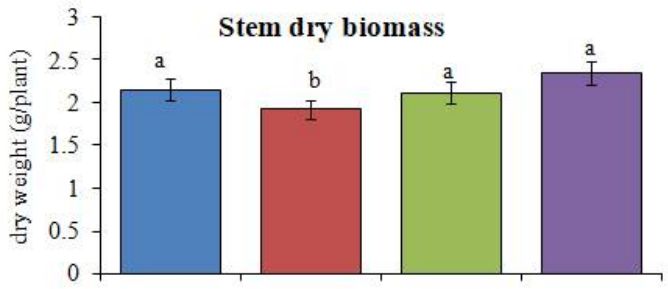

e)

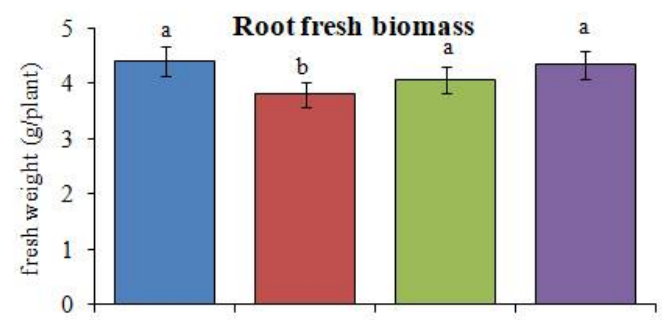

f)

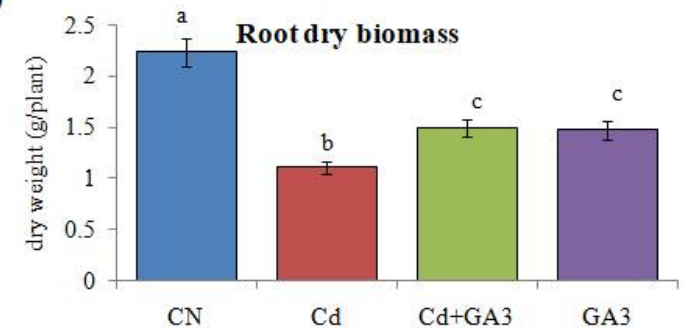

Figure 3. Effect of $\mathrm{GA}_{3}$ on the biomass of mung bean plants under cadmium (Cd) stress in soil.Effect of $\mathrm{GA}_{3}$ with or without cadmium (Cd) stress on fresh leaf biomass (a), dry leaf biomass (b), stem fresh biomass (c), stem dry biomass (d), root fresh biomass (e) and root dry biomass (f) of mung bean plants grown in soil in pots at time of harvest. Control $(\mathrm{CN})$, cadmium $(\mathrm{Cd})$ stress, $\mathrm{Cd}+$ gibberellins $\left(\mathrm{GA}_{3}\right)$, and $\mathrm{GA}_{3}$ alone conditions. Data presented are means \pm standard errors $(n=10$, biological replicates). Different letters $(\mathrm{a}, \mathrm{b}, \mathrm{c})$ indicate significant differences from control in all combinations (Tukey's test, $p \leq 0.05$ ).

\subsection{Effect of $\mathrm{GA}_{3}$ on Photosynthetic Pigments and Soluble Sugar under Cd Stress}

Photosynthetic pigments suffered damage under $\mathrm{Cd}$ stress such that a consistent decrease in Chla content at all the observation points (30, 45, 60, and 75 DAS), with maximum reduction (55\%) occurred at 30 DAS compared to control (Table 1). GA 3 could improve Chla content consistently, with a maximum increase (75\%) recorded at 30 DAS over $\mathrm{Cd}$ alone treated plants. $\mathrm{GA}_{3}$ alone improved $\mathrm{Chl} a$ content at all observation points, with 
maximum enhancement (20\%) noted at 75 DAS compared to control plants (Table 1 ). Contrary to $\mathrm{Chl} a$, under $\mathrm{Cd}$ stress, $\mathrm{Chl} b$ content showed a consistent increase at all observation points, with a maximum increase $225 \%$ recorded at 60 DAS compared to control plants. Furthermore, $\mathrm{GA}_{3}$ could increase $\mathrm{Chl} b$ content throughout the experiment, with maximum improvement (52\%) noted at 30 DAS over Cd alone treated plants (Table 1). GA 3 alone could improve $\mathrm{Chl} b$ content at all the observation points, with a maximum increase (157\%) being recorded at 30 DAS compared to control plants. For carotenoids (CARs), under Cd stress, content showed an upward trend, with a maximum increase (59\%) noted at 30 DAS over control plants. $\mathrm{GA}_{3}$ improved CAR content maximally $(66 \%)$ at 75 DAS compared to only Cd-treated plants. $\mathrm{GA}_{3}$ alone could improve CAR content at all the observation points, with a maximum increase (232\%) recorded at 30 DAS compared to control plants (Table 1 ). Total soluble sugars (TSS) amount was significantly reduced at 30, 45, 60, and 75 DAS in Cd stressed plants compared to control. $\mathrm{GA}_{3}$ supplied to $\mathrm{Cd}$ stressed plants significantly enhanced TSS by $81 \%$ and $100 \%$ at 60 and 75 DAS than Cd alone treated plants. $\mathrm{GA}_{3}$ alone could improve TSS significantly at 75 DAS over control plants (Table 1).

\subsection{Effect of $\mathrm{GA}_{3}$ on Stress Indices and Antioxidant System in Pot Experiments}

Stress indices such as malondialedhye (MDA, membrane damage indicator) and proline (PL) play a significant role in evaluating the physiological status of a plant under abiotic stress. In the present study, Cd stress was shown to increase MDA content at all the observation points, with the most significant membrane damage (87\%) recorded at 60 DAS compared to control plants (Table 1). GA 3 could bring a decline in MDA content in Cd stressed plants maximally at 75 DAS over Cd-treated plants. $\mathrm{GA}_{3}$ alone significantly increased MDA (34\%) at 45 DAS compared to control plants. Under Cd stress, PL content increased sharply, with a maximum increase $(270 \%)$ at 60 DAS compared to control plants. $\mathrm{GA}_{3}$ supplementation to $\mathrm{Cd}$ stressed plants further improved PL content at all the observation points, with a maximum increase $(86 \%)$ recorded at 45 DAS over $\mathrm{Cd}$ alone treated plants. A consistent increase in PL occurred under $\mathrm{GA}_{3}$ alone, with a maximum increase $(170 \%)$ noted at 60 DAS over control plants (Table 1$)$.

Among antioxidants, total phenol content (TPC) increased maximally (25\%) at 60 DAS in Cd stressed plants compared to control plants (Table 1). GA 3 applied to Cd stressed plants showed a decline in TPC content at all the observation points, with maximum reduction (24\%) noted at 75 DAS over Cd alone treated plants. In comparison, $\mathrm{GA}_{3}$ alone treated plants showed a maximum increase in TPC (30\%) at 30 DAS (Table 1$)$.

\subsection{Effect of $\mathrm{GA}_{3}$ on Accumulation, Translocation, and Localization of Cd Ions}

Compared to control plants, Cd stressed plants showed $61 \%, 126 \%$, and $88 \%$ higher accumulation of $\mathrm{Cd}$ in leaf, shoot, and root tissue (Figure $4 \mathrm{a}$ ). $\mathrm{GA}_{3}$ application to $\mathrm{Cd}$ stressed plants reduced accumulation of $\mathrm{Cd}$ by $35 \%, 34 \%$, and $46 \%$ in leaf, shoot, and root tissues compared to $\mathrm{Cd}$ alone treated plants (Figure $4 \mathrm{a}$ ). Bioaccumulation factor (BAF) from soil to root transfer of $\mathrm{Cd}$ showed a marked increase by 14.5 fold-over soil concentration of $\mathrm{Cd}$ alone (Figure $4 \mathrm{~b}$ ). $\mathrm{GA}_{3}$ application to $\mathrm{Cd}$ stressed plants showed a significant reduction of BAF of roots from the soil by 7.8-fold compared to BAF in Cd alone (by 14.5-fold) (Figure $4 \mathrm{~b}$ ). Translocation factor (TF) from shoot-leaf showed no major change in $\mathrm{Cd}$ alone, and $\mathrm{Cd}$ stressed plants supplemented with $\mathrm{GA}_{3}$ (Figure 4c). About 75\% and 65\% accumulation of $\mathrm{Cd}$ has been noted in pods and seeds of $\mathrm{Cd}$ stressed plants compared to control plants grown in soil in pots. $\mathrm{GA}_{3}$ application reduced $\mathrm{Cd}$ accumulation by $67 \%$ and $89 \%$ in pods and seeds compared to $\mathrm{Cd}$ alone treated plants. Compared to $\mathrm{Cd}$ stressed plants, significant reductions in $\mathrm{Cd}$ ions accumulation were recorded in pods and seeds applied with $\mathrm{GA}_{3}$ plus $\mathrm{Cd}$ (Figure $4 \mathrm{~d}$ ). For histological localization of $\mathrm{Cd}^{2+}$ ions, white crystalline precipitates of $\mathrm{Cd}$ oxalate were observed in the transverse sections (T.S.) of the stem of plants under $\mathrm{Cd}$ stress. Localization was more pronounced in the cortex areas of $\mathrm{Cd}$ stressed plants, while $\mathrm{Cd}$ oxalate crystals were few in $\mathrm{GA}_{3}$ applied $\mathrm{Cd}$ plants (Figure $4 \mathrm{e}-\mathrm{h})$. 
a)

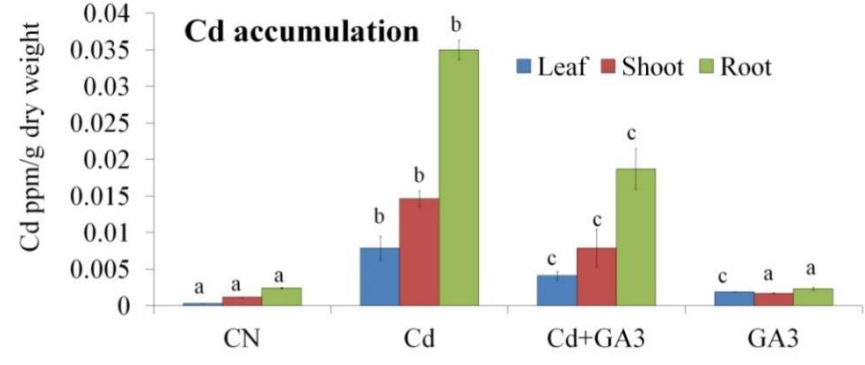

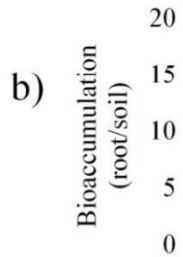

c)

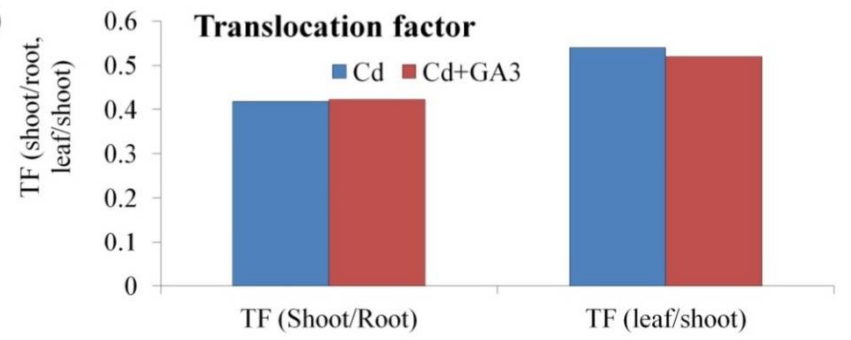

d)

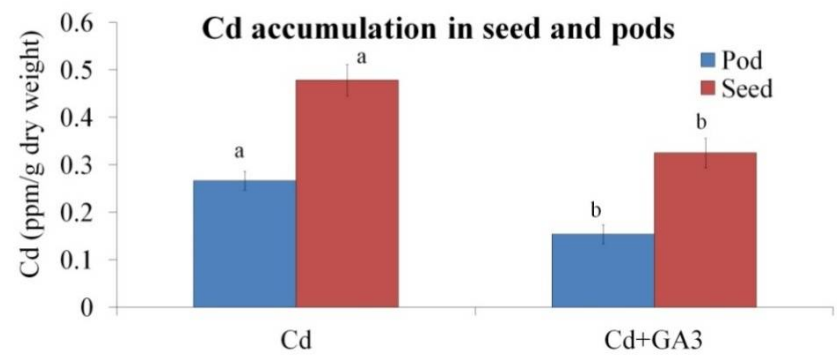

BAF

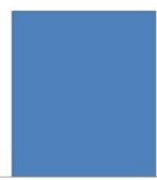

$\mathrm{Cd}$

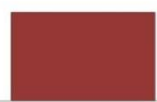

$\mathrm{Cd}+\mathrm{GA} 3$
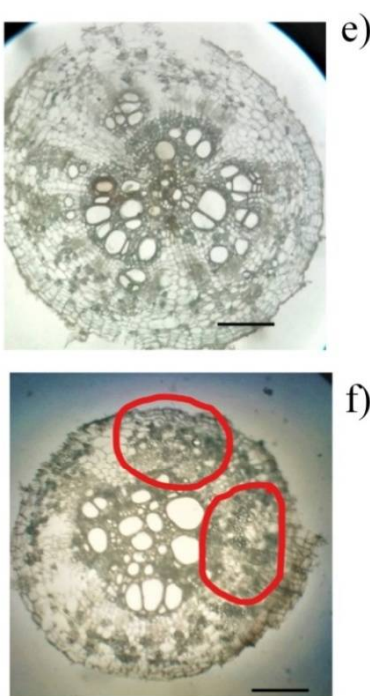

f)
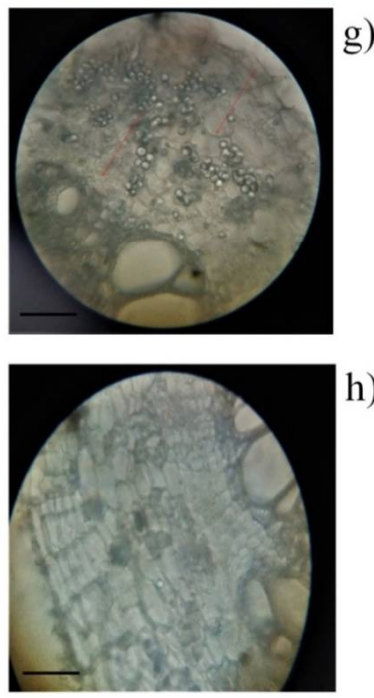

Figure 4. Effect of $\mathrm{GA}_{3}$ on accumulation, translocation, and localization of cadmium (Cd) in mung bean plants. Effect of $\mathrm{GA}_{3}$ on cadmium (Cd) accumulation (ppm/g dry weight) in leaf, shoot, and root tissue (a), bioaccumulation factor (BAF, Cd accumulation root/soil) (b), translocation factor (shoot/root and leaf/shoot) (c), Cd accumulation (ppm/g dry weight) in pods and seeds (d), and histological localization of $\mathrm{Cd}$ ions as $\mathrm{Cd}$-oxalate white crystals in stem tissue transverse sections, $\mathrm{Cd}$ alone $(\mathbf{f}, \mathbf{g})$ and $\mathrm{GA}_{3}$ pus $\mathrm{Cd}(\mathbf{e}, \mathbf{h})$ of mung bean plants grown in soil in pots at time of harvest. Control $(\mathrm{CN})$, cadmium $(\mathrm{Cd})$ stress, $\mathrm{Cd}+$ gibberellins $\left(\mathrm{GA}_{3}\right)$, and $\mathrm{GA}_{3}$ alone conditions. Data presented are means \pm standard errors ( $n=10$, biological replicates) for $(\mathbf{a}-\mathbf{c})$. Scale bars: $1000 \mu \mathrm{m}$ for $(\mathbf{e}, \mathbf{f})$ and $100 \mu \mathrm{m}$ for (g,h). Red circles and red arrows represent the localization of Cd oxalate crystals. Different letters $(a, b, c)$ indicate significant differences from control in all combinations (Tukey's test, $p \leq 0.05$ ).

\subsection{Effect of $\mathrm{GA}_{3}$ on Genes Regulating $\mathrm{Cd}$ Uptake and Transport}

Expression of genes inducing $\mathrm{Cd}^{2+}$ ions sequestration was enhanced under $\mathrm{Cd}$ stress compared to the control. Such that 1.7, 2.5, 1.6-fold increase in expression of VrPCS1, VrIRT1, and VrIRT2 was noted in Cd stressed seedlings compared to control. GA 3 application further elevated expressions of VrPCS1, VrIRT1 and VrIRT2 over Cd treatment (Figure $5 \mathrm{a}-\mathrm{c}$ ). $\mathrm{GA}_{3}$ alone could not modulate expressions of these genes significantly compared to control. Increase in uptake of $\mathrm{Cd}$ ions under $\mathrm{Cd}$ stressed plants over control was linked with elevated expression of VrIRT1 and VrIRT2 over control plants. $\mathrm{GA}_{3}$ application lowered $\mathrm{Cd}$ accumulation in young plants; this reduction in $\mathrm{Cd}$ ions accumulation could be attributed to a decline in expression of VrIRT1 and VrIRT2 compared to only Cd-treated 
seedlings (Figure $5 \mathrm{~b}, \mathrm{c}$ ). $\mathrm{GA}_{3}$ alone also improved $\operatorname{VrIRT1}$ expression over control though insignificantly compared to control. Elevated expression, 2.2-fold of $\operatorname{VrCDR} 29$ noted in Cd stress alone compared to control. $\mathrm{GA}_{3}$ application to $\mathrm{Cd}$ stress further improved $\operatorname{VrCDR} 29$ expression by 1.7 -fold compared to only $\mathrm{Cd}$ treatment (Figure $5 \mathrm{~d}$ ).
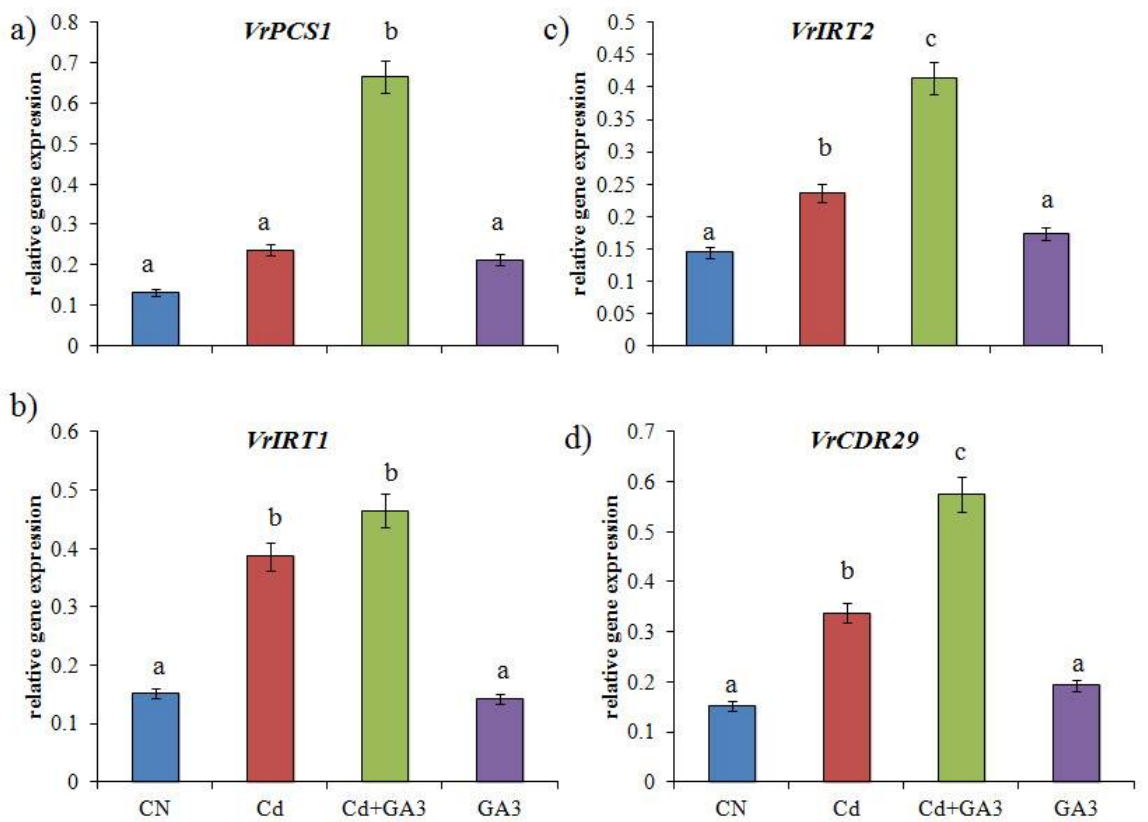

Figure 5. Effect of $\mathrm{GA}_{3}$ on the relative gene expression of Vigna radiata phytochelatin synthase 1 (VrPCS1), (a), VrIron transporter 1 (VrIRT1) (b), VrIron transporter 2 (VrIRT2) (c) and Vr cadmium response $(\operatorname{VrCDR} 29)(\mathbf{d})$ in young seedlings subjected to Control $(\mathrm{CN})$, cadmium $(\mathrm{Cd})$ stress, $\mathrm{Cd}+$ gibberellins $\left(\mathrm{GA}_{3}\right)$, and $\mathrm{GA}_{3}$ alone conditions in paper roll method. Data presented are means \pm standard errors ( $n=3$, biological replicates). Different letters $(\mathrm{a}, \mathrm{b}, \mathrm{c})$ indicate significant differences from control in all combinations (Tukey's test, $p \leq 0.05$ ).

\section{9. $\mathrm{GA}_{3}$ Improves Agronomic Traits Affected by $\mathrm{Cd}$ Stress}

A visible reduction in pod length and seed size was observed under $\mathrm{Cd}$ stress, while $\mathrm{GA}_{3}$ application could mitigate negative impacts of $\mathrm{Cd}$ stress on pod length and seed size (Figure 6). For pod length, Cd-treated plants showed $21 \%$ reduction, while $\mathrm{GA}_{3}$ improved pod length by $11 \%$ in $\mathrm{Cd}$ stressed plants over $\mathrm{Cd}$ alone (Figure 7a). Cd-treated plants showed an $8 \%$ reduction in pod diameter compared to control plants. $\mathrm{GA}_{3}$ could improve pod diameter by $17 \%$ in $\mathrm{Cd}$ stressed plants (Figure $7 \mathrm{~b}$ ). $\mathrm{GA}_{3}$ applied alone increased pod diameter by $58 \%$ over control plants (Figure $7 \mathrm{~b}$ ). Approximately $34 \%$ reduction in pod number/plant was recorded in Cd stressed plants over control plants.

About $25 \%$ increase in pod number/plant was recorded for $\mathrm{GA}_{3}$ applied $\mathrm{Cd}$ stressed plants over $\mathrm{Cd}$ alone treated plants. No significant change in pod number/plant was recorded for alone $\mathrm{GA}_{3}$ treated plants over control plants (Figure 7c). About $49 \%$ and $52 \%$ reduction in pod fresh and pod dry weight was noted in Cd stressed plants compared to control plants. $\mathrm{GA}_{3}$ in $\mathrm{Cd}$ stressed plants showed significant improvement in pod fresh $(57 \%)$ and pod dry weight $(107 \%)$ over $\mathrm{Cd}$ alone treated plants (Figure $7 \mathrm{~d}, \mathrm{e})$. Interestingly, a $108 \%$ and $237 \%$ increase in pod fresh and pod dry weight was recorded for alone $\mathrm{GA}_{3}$ treated plants compared to control plants (Figure 7d,e). 


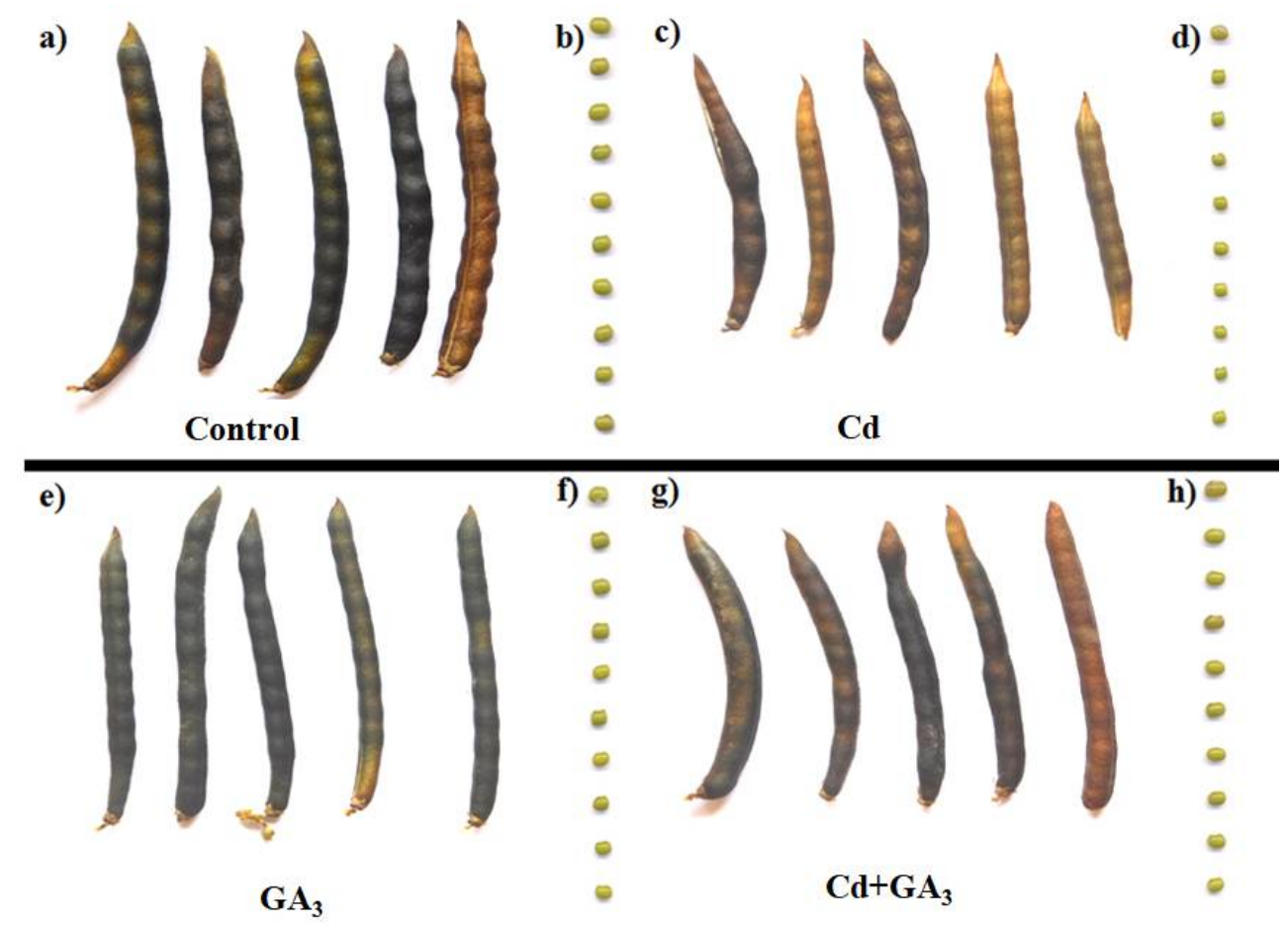

Figure 6. Effect of $\mathrm{GA}_{3}$ on pod and seed size attributes under $\mathrm{Cd}$ stress. Control $(\mathrm{CN},(\mathbf{a}, \mathbf{b})), \mathrm{Cd}$ stress $(\mathrm{Cd},(\mathbf{c}, \mathbf{d})), \mathrm{GA}_{3}(\mathbf{e}, \mathbf{f})$ and $\mathrm{Cd}+\mathrm{GA}_{3}(\mathbf{g}, \mathbf{h})$ conditions.

For seed, Cd stress was able to influence several important seed attributes viz. seed number/ten pods for normal and aborted seeds, 100 seeds weight, seeds weight/pod, seed width $(\mathrm{W})$, seed length $(\mathrm{L})$, seed thickness $(\mathrm{T})$, seed surface area (SA), mean geometric diameter $\left(\mathrm{D}_{\mathrm{g}}\right)$, sphericity $(\Phi \%)$, seed volume $(\mathrm{V})$ and seed germination percentage $(\% \mathrm{G})$. Such that $19 \%, 40 \%$, and $47 \%$ reduction in seed number/ten pods, 100 seeds weight and seed weight/pod was recorded in Cd stressed plants over control plants. However, $\mathrm{GA}_{3}$ application in Cd stressed plants showed $32 \%, 35 \%$, and $67 \%$ improvement in these seed attributes over alone Cd-treated plants (Figure $7 \mathrm{f}-\mathrm{h}$ ). $\mathrm{GA}_{3}$ alone improved seed number/ten pods by $9.5 \%$ and reduced 100 seeds weight and seed weight/pod by $20 \%$ and $10 \%$, respectively, compared to control plants (Figure $7 \mathrm{f}-\mathrm{h}$ ). For seed geometric attributes, about $13 \%, 15 \%, 14 \%$, and $16 \%$ reduction in $\mathrm{W}, \mathrm{L}, \mathrm{T}$, and seed surface area (SA) was recorded in Cd stressed plants compared to control plants (Figure 7i, Table 2). GA 3 application to Cd stressed plants improved W, L, T, and SA by $8.47 \%, 15.29 \%, 8.23 \%$, and $13.27 \%$, respectively, over $\mathrm{Cd}$ alone treated plants. Similarly, $13.77 \%$ and $35.89 \%$ reduction in $\mathrm{D}_{\mathrm{g}}$, and $\mathrm{V}$ was recorded in Cd stressed plants over control plants. $\mathrm{GA}_{3}$ application in $\mathrm{Cd}$ stressed plants showed $10.46 \%$ and $34.79 \%$ improvement in $\mathrm{D}_{\mathrm{g}}$, and $\mathrm{V}$ over Cd alone treated plants. Contrary, $\mathrm{GA}_{3}$ application alone reduced $\mathrm{D}_{\mathrm{g}}$ by $8.31 \%$ and $\mathrm{V}$ by $22.91 \%$ compared to control plants alone. While no significant change in $\Phi \%$ was recorded in $\mathrm{Cd}$ stressed plants, though an insignificant decrease of $4 \%$ was recorded for $\mathrm{GA}_{3}$ applied Cd stressed plants compared to alone $\mathrm{Cd}$-treated plants (Table 2). Seed protein content under $\mathrm{Cd}$ stress declined $36 \%$ compared to control seeds. Application of $\mathrm{GA}_{3}$ in $\mathrm{Cd}$ stressed plants further declined seed protein content by $20 \%$ over Cd-treated plants. Interestingly, seed protein content declined by $35 \%$ in $\mathrm{GA}_{3}$ alone treated plants over control plants (Table 2). Seed sugar content decreased significantly in $\mathrm{Cd}$ stressed plants over control (Figure 7j). GA 3 alone or with $\mathrm{Cd}$ stress improved seed sugar content significantly (Figure 7j). Seed TPC in Cd stressed plants showed a significant increase $(241 \%)$ over control plants. GA $_{3}$ applied $\mathrm{Cd}$ stressed plants showed a 92\% reduction in seed TPC over TPC of seeds of $\mathrm{Cd}$ alone treated plants. About $43.46 \%$ reduction in seed TPC was noted in alone GA treated plants compared to control (Table 2). 
a)
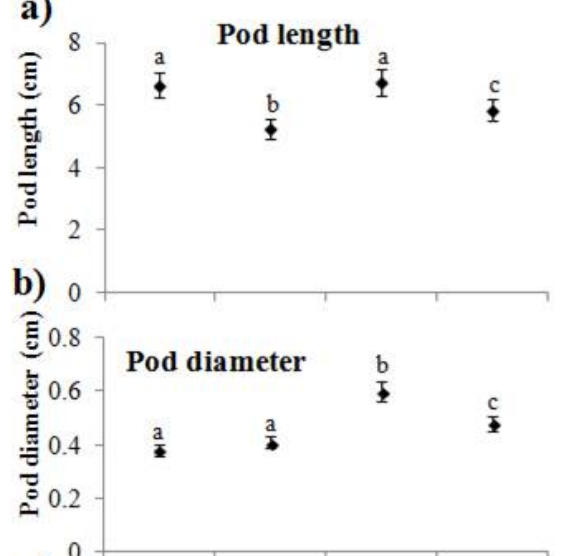

c)
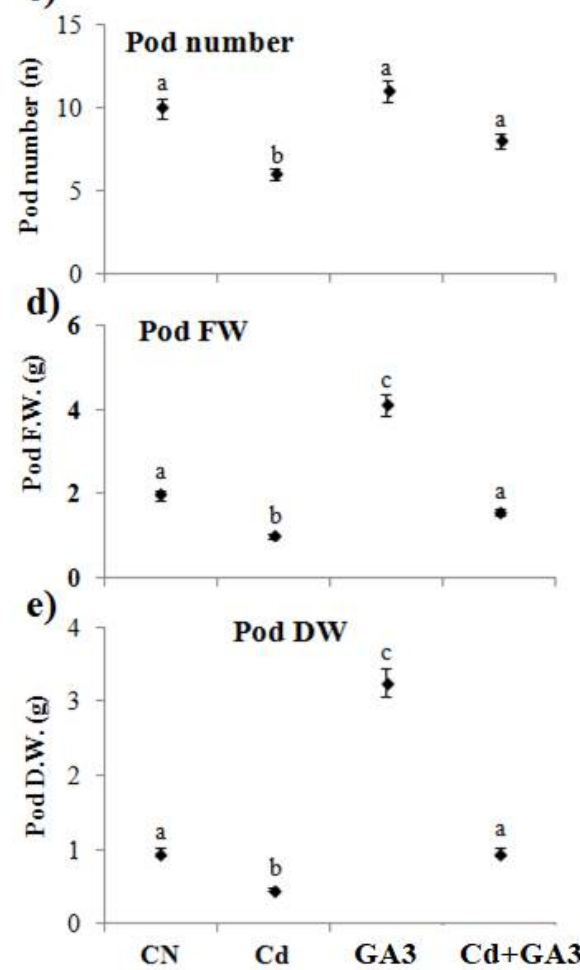

f)

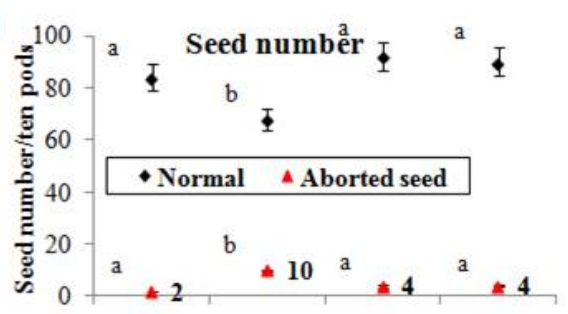

g)

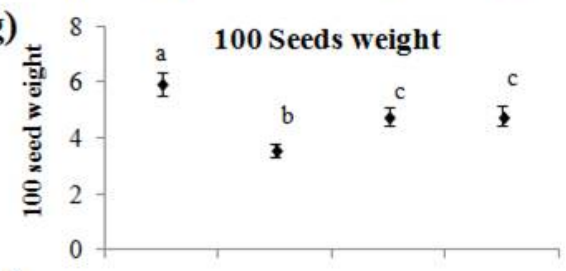

h)

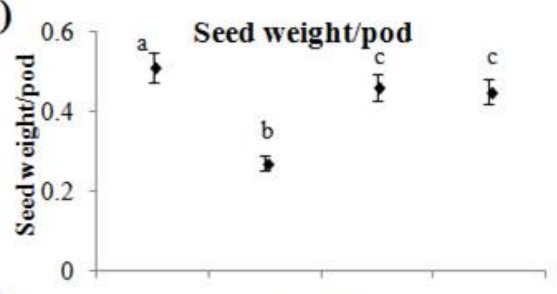

i)

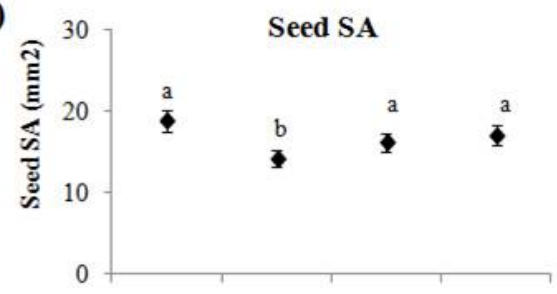

j)

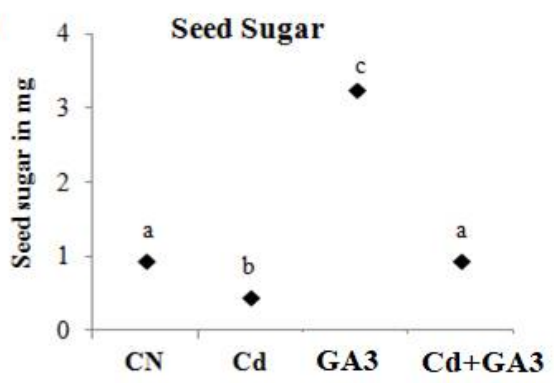

Figure 7. Effect of $\mathrm{GA}_{3}$ with or without cadmium (Cd) stress on pod length (a), pod diameter (b), pod number/plant (c), pod fresh weight/plant (Pod FW, d), pod dry weight (Pod DW, e), normal and aborted seed number/ten pods (f), hundred seeds weight (g), seed weight/pod (h), seed surface area(SA) (i) and seed sugar (j) of mung bean plants grown in soil in pots at time of harvest. Control $(\mathrm{CN})$, cadmium $(\mathrm{Cd})$ stress, $\mathrm{Cd}+$ gibberellins $\left(\mathrm{GA}_{3}\right)$, and $\mathrm{GA}_{3}$ alone conditions. Data presented are means \pm standard errors ( $n=10$, biological replicates). Different letters $(a, b, c)$ indicate significant differences from control in all combinations (Tukey's test, $p \leq 0.05$ ). 


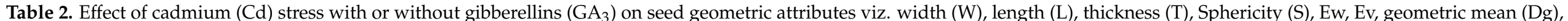

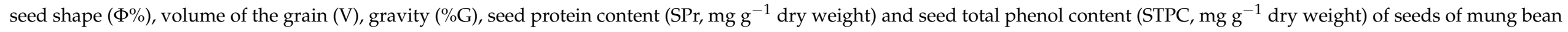

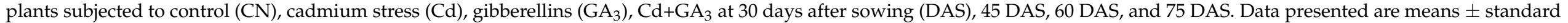
errors ( $n=10$, biological replicates). Different letters $(a, b, c)$ indicate significant differences from control in all combinations (Tukey's test, $p \leq 0.05)$.

\begin{tabular}{|c|c|c|c|c|c|c|c|c|c|c|c|c|}
\hline Treatment & $W$ & $\mathrm{~L}$ & $\mathrm{~T}$ & $\mathrm{~S}$ & $\mathrm{E}_{\mathrm{w}}$ & $E_{v}$ & $D_{g}$ & $\Phi \%$ & $\mathrm{~V}$ & $\% G$ & SPr & STPC \\
\hline $\mathrm{CN}$ & $3.94 \pm 0.13 \mathrm{a}$ & $4.85 \pm 0.20 \mathrm{a}$ & $3.95 \pm 0.27 \mathrm{a}$ & $17.27 \mathrm{a}$ & $1.23 \mathrm{a}$ & $0.99 \mathrm{a}$ & $4.21 \pm 0.25 \mathrm{a}$ & $86.76 \mathrm{a}$ & 39.76 & $95 \mathrm{a}$ & $1.08 \mathrm{a} \pm 0.01$ & $0.63 \pm 0.002$ \\
\hline $\mathrm{Cd}$ & $3.42 \pm 0.24 b$ & $4.12 \pm 0.66 \mathrm{~b}$ & $3.40 \pm 0.26 b$ & $14.46 \mathrm{~b}$ & $1.20 \mathrm{a}$ & $1.00 \mathrm{a}$ & $3.63 \pm 0.21 b$ & $87.97 \mathrm{a}$ & 25.49 & $52 \mathrm{~b}$ & $0.69 \mathrm{~b} \pm 0.002$ & $2.17 \pm 0.025$ \\
\hline $\mathrm{Cd}+\mathrm{GA}_{3}$ & $3.71 \pm 0.24 \mathrm{a}$ & $4.75 \pm 0.48 \mathrm{a}$ & $3.68 \pm 0.23 \mathrm{a}$ & $16.38 \mathrm{a}$ & $1.28 \mathrm{~b}$ & $1.00 \mathrm{a}$ & $4.01 \pm 0.24 \mathrm{a}$ & $84.39 \mathrm{a}$ & 34.36 & $78 \mathrm{c}$ & $0.55 b \pm 0.001$ & $0.17 \pm 0.001$ \\
\hline $\mathrm{GA}_{3}$ & $3.60 \pm 0.24 \mathrm{a}$ & $4.51 \pm 0.33 \mathrm{a}$ & $3.55 \pm 0.17 b$ & $15.65 \mathrm{a}$ & $1.25 \mathrm{a}$ & $1.01 \mathrm{a}$ & $3.86 \pm 0.23 a$ & $85.57 \mathrm{a}$ & 30.65 & $97 \mathrm{a}$ & $0.70 \mathrm{a} \pm 0.001$ & $0.36 \pm 0.001$ \\
\hline
\end{tabular}




\subsection{Pearson Correlation Analysis}

A significant linear correlation $(r)$ for stem height, stem diameter, and leaf number were noted for Cd stress alone (Table 3). Pearson's correlation coefficient $(r)$ for shoot traits under $\mathrm{Cd}$ stress showed linear correlation; however, a significant positive correlation was noted for stem diameter (Table 3). A negative correlation was noted for root length under $\mathrm{Cd}$ stress (Table 3). $\mathrm{GA}_{3}$ applied to $\mathrm{Cd}$ stressed plants showed a positive correlation for stem diameter, leaf number, and root length, while a negative correlation noted for stem height and leaf surface area (Table 3). For agronomic traits, seed number, seed weight, seed weight/pod showed a positive correlation with Cd stress, while a negative correlation was found for seed surface area (Table 3). While all agronomic traits except seed number showed a negative correlation between $\mathrm{GA}_{3}$ applied $\mathrm{Cd}$ stressed plants and $\mathrm{Cd}$ alone treated plants (Table 3).

Table 3. Pearson correlation coefficient $(r)$ for ten traits of plant fitness (stem height, stem diameter, leaf number, leaf surface area, and root length) and of agronomical attributes (seed number, seed weight, seed weight/pod, seed surface area) for Control versus $\mathrm{Cd}$, Control versus $\mathrm{Cd}+\mathrm{GA}_{3}$ and Control versus $\mathrm{GA}_{3}$.

\begin{tabular}{|c|c|c|c|c|c|}
\hline & \multicolumn{5}{|c|}{ Pearson Correlation for Morphometeric Traits } \\
\hline & Stem Height & Stem Diameter & Leaf Number & Leaf Surface Area & Root Length \\
\hline $\mathrm{CN}$ & 1 & 1 & 1 & 1 & 1 \\
\hline $\mathrm{Cd}$ & 0.364 & $0.593 *$ & 0.014 & 0.447 & -0.289 \\
\hline $\mathrm{Cd}+\mathrm{GA}_{3}$ & -0.050 & 0.875 & $0.582 *$ & -0.061 & 0.473 \\
\hline \multicolumn{6}{|c|}{ Pearson Correlation for Agronomic Traits } \\
\hline & Seed Number & Seed Weight & Seed Weight/Pod & Seed Surface Area & \\
\hline $\mathrm{CN}$ & 1 & 1 & 1 & 1 & \\
\hline Cd & 0.127 & 0.075 & 0.295 & -0.156 & \\
\hline $\mathrm{Cd}+\mathrm{GA}_{3}$ & 0.088 & -0.413 & -0.400 & -0.032 & \\
\hline
\end{tabular}

Number of biological replicates $(n=13)$ across treatments. Asterisk * represents whether the correlation is significant at the 0.05 level (2-tailed).

\section{Discussion}

Cadmium (Cd) is a nonessentialheavy metal known to affect human health and plant growth and metabolism [2,40]. Being highly active Cd, its excess in soil often accounts for perturbed metabolism and growth defects leading to reduced yield in crops of commercial importance [4]. The decrease in shoot and root lengths and fresh and dry biomass, due to heavy-metal stress has been reported in mungbean [8], Arachis hypogea [41], and sunflower [42]. The reduction in plant height under Cd stress can be supported with similar observations recorded in Vigna radiata (L.) Wilzeck cultivars PDM-139 and K-851 subjected to $0.2 \mathrm{mg} / \mathrm{L}$ of $\mathrm{Cd}$ exposure showed a significant reduction in plant height [43]. However, improved plant height recorded in Cd stressed plants upon application of $\mathrm{GA}_{3}$ compared to $\mathrm{Cd}$ stressed plants could be attributed to the positive impact of $\mathrm{GA}_{3}$ on inducing plant growth (Figure 1). Our observations are supported by similar findings, wherein application of GA $(50 \mu \mathrm{M})$ to Brassica napus L. grown in Cd (0, 50, and $100 \mu \mathrm{M})$ hydroponics could increase plant height compared to only Cd hydroponics [44]. Similar to our observations of reduced leaf number and leaf SA in mung bean plants under Cd stress, reduction in leaf number and leaf SA have been reported in V. radiata (L.) Wilczekwas subjected to increased levels of $\mathrm{Cd}$ in the soil medium [45]. Improved leaf SA of Cd stressed plants applied with $\mathrm{GA}_{3}$ could be linked with the established impact of GAs on the leaf elongation rate (LER)viaactivating expression of genes of cell elongation, i.e., $\alpha$-expansins, one $\beta$-expansin, and xyloglucanendotransglycosylase [46]. Reductions in both fresh and dry biomasses of $\mathrm{Cd}$ stressed plants could be attributed to $\mathrm{Cd}$ interference in the normal functioning of enzymes of the Calvin cycle, $\mathrm{CO}_{2}$ fixation, phosphorus, and carbohydrate metabolism leading to stunted plant growth and inhibition of photosynthesis $[19,47]$. 
Plants often respond to soil HM stress by reducing root length and root surface area, to minimize the root area exposition to HM pollution [48]. The decrease in root length, root surface area, and root biomass both in young plants (Experiment 1) and mature plants (Experiment 2). The role of $\mathrm{Cd}$ in decreasing nodulation and activity of nitrogen metabolizing enzymes has been established [49]. Higher concentrations of Cd have been observed to induce nodule senescence and decrease in legHb content in leguminous plants [49]. Contrary to earlier reports, $\mathrm{Cd}$ stress was observed to increase nodule number/plant over control plants; interestingly, this increase in nodule number/plant was found to be associated with a significant reduction in nodule diameter and nodule surface area. However, the application of $\mathrm{GA}_{3}$ was able to improve nodule diameter at all observation points with a maximum increase recorded at 75 DAS compared to only Cd stressed plants. Similar to observations reported earlier, $\mathrm{Cd}$ stress loweredthe nodule legHb content significantly over control plants; however, supplementation of $\mathrm{GA}_{3}$ to $\mathrm{Cd}$ stressed plants showed improvement in nodule leg $\mathrm{Hb}$ content. This reduction in legHb content under $\mathrm{Cd}$ stress could be attributed to the production of a higher number of reactive oxygen species with a detrimental impact on nodules [50].

A positive correlation existed between the accumulation of $\mathrm{Cd}$ in shoot tissue and its localization. Significantly accumulated Cd in Cd stressed plants followed shoot $>$ root $>$ leaf, while $\mathrm{GA}_{3}$ application could reduce $\mathrm{Cd}$ accumulation and root-shoot and shoot to leaf translocation significantly. Similarly, the accumulation of $\mathrm{Cd}$ was higher in pods than seeds, while $\mathrm{GA}_{3}$ application reduced this accumulation by a significant factor. This significant reduction in $\mathrm{Cd}$ accumulation in $\mathrm{GA}_{3}$ treated plant tissues and its translocations from root to shoot and shoot to leaf could be linked with elevated expressions of genes regulating $\mathrm{Cd}$ uptake $(V g C D R)$, phytochelatin synthesis ( $V g P C S 1$ and $V g P C S 2)$, and $V g I R T 1$ compared to Cd stressed plants.

Reductions in photosynthetic pigments (Chla, Chl $b$ and CAR) in Cd stressed plants may be linked to the inhibitory impact of $\mathrm{Cd}$-induced generation of ROS and lipid peroxidation and inhibiting $\mathrm{Chl}$ biosynthesis by competing with $\mathrm{Mg}$ ions, consequently leading to damage of PS II [51]. Application of $\mathrm{GA}_{3}$ ameliorated the negative impact of Cd on photosynthetic pigmentsviareducing the production of ROS and damage to the cell membrane by improving antioxidant activity of $\mathrm{Cd}$ stressed plants compared to $\mathrm{Cd}$ alone treated plants. Exogenous applications of $\mathrm{GA}_{3}$ have been shown to improve the contents of photosynthetic pigments by stabilizing and inhibiting the dissociation of the light-harvesting complex from PS II core, under Cu stress in Helianthus annuus L. [52].

Cd stressed plants showed an increase in membrane damage as indicated by enhanced levels of MDA throughout the plant's life cycle after the imposition of $\mathrm{Cd}$ stress. Application of $\mathrm{GA}_{3}$ was observed to reduce membrane damage in Cd stressed plants, probably via reducing the production of ROS compared to Cd stressed plants (Table 1). Findings agree with Cd-induced membrane damage and higher production of superoxide radicals and membrane lipid peroxidation products recorded in seedlings of Vigna aconitifolia L. [53]. Enhanced levels of PL in Cd stressed plants could be linked with effective HM stress management; moreover, $\mathrm{GA}_{3}$ induced further increase in PL content in $\mathrm{Cd}$ stressed plants can be associated with reducing ROS production. $\mathrm{GA}_{3}$ induced increase in PL production and its implication in bud outbreak has been recorded in Prunus avium (sweet cherry) [54].

Phenolic acids play pivotal roles in abiotic stress management, particularly by neutralizing or scavenging ROS. TPC is a good indicator of total phenolics content in a plant system under abiotic stresses in plants. In the present work, enhanced TPC in Cd stressed plants could be linked with the plant's inbuilt response towards enhanced ROS production and their management. While $\mathrm{GA}_{3}$ induced a small decrease in TPC of Cd stressed plants could be attributed to the reduction of ROS levels and returning of normal growth conditions compared to Cd stressed plants. Enhanced levels of total phenolics in GA-treated Vitis vinifera L. cv. Muscat has been recorded to play important roles in the development of grapevine tissues [55]. Soil HM pollution has been shown to affect the activity of nitrogen metabolism enzymes such as urease and nitrification dynamics in the soil-rhizosphere 
zone [56]. At low concentrations ( $0.5 \mathrm{mg} / \mathrm{kg}$ soil), $\mathrm{Cd}^{2+}$ cations were able to up-regulate the urease activity; though at higher concentration activity got declined considerably [56]. Similar observations were also recorded for $\mathrm{Cd}$ stressed plants and elevated activity of urease activity in $\mathrm{GA}_{3}$ applied plants.

$\mathrm{Cd}$ stress has been observed to reduce agronomic traits of $V$. radiata L. [15], such that plants subjected to $3,6,9$, and $12 \mathrm{mg} / \mathrm{kg}$ soil Cd toxicity showed a reduction in the number of pod/plant, pod length, pod fresh weight, pod dry weight, number of seeds/pod and number of seeds/plant [15]. This investigation also witnessed a reduction in pod size, pod length, pod diameter, pod fresh and dry weights, seed number/pod and plant, seed weight under $\mathrm{Cd}$ stress (Figures 6 and 7). Besides, reduced seed surface area, sugar content, protein content, and geometric attributes were also noted under $\mathrm{Cd}$ stress. $\mathrm{GA}_{3}$ supplementation was able to significantly mitigate the negative impact of $\mathrm{Cd}$ stress on all the prementioned agronomic attributes.

A Pearson correlation analysis also revealed the negative impact of $\mathrm{Cd}$ stress on agronomic and growth parameters of vigna plants. Moreover, $\mathrm{GA}_{3}$ application improvedthe negative impact of $\mathrm{Cd}$ stress on the growth and agronomic traits considerably. Due to these findings, we propose the application of $\mathrm{GA}_{3}$ for significantly reducing the $\mathrm{Cd}$ stressassociated damages in mung plants.

\section{Conclusions}

Thisstudy demonstrated the negative impact of $\mathrm{Cd}$ toxicity on mung bean plants at the morphological, physiological, and agronomical level. $\mathrm{GA}_{3}$ application was observed to reduce $\mathrm{Cd}$-induced stress through several morphological and physiological adaptations without compromising economic attributes. Wepropose $\mathrm{GA}_{3}$ application for the management of $\mathrm{Cd}$-induced stress in mung bean plants.

Author Contributions: Conceptualization: S.P., N.S.Y. and A.A.H.A.L.; methodology; H.R.H., M.U., S.S., P.R. and D.K.; software: S.P.; validation: S.P., H.R.H., M.U., S.S., P.R. and D.K.; formal analysis: H.R.H., M.U., S.S. and D.K.; investigation: H.R.H., M.U., S.S. and D.K.; writing-original draft preparation: S.P., N.S.Y. and A.A.H.A.L.; writing-review and editing: S.P., N.S.Y. and A.A.H.A.L.; visualization: S.P.; supervision: S.P. and A.A.H.A.L.; project administration: S.P.; funding acquisition: S.P. and A.A.H.A.L. All authors have read and agreed to the published version of the manuscript.

Funding: This research was funded by UGC-SAP-DRS, and Taif University Researchers Supporting Project number (TURSP-2020/72), Taif University, Taif, Saudi Arabia.

Institutional Review Board Statement: Not applicable.

Informed Consent Statement: Not applicable.

Data Availability Statement: Not applicable.

Acknowledgments: Authors would like to thank Department of Botany, University of Jammu for extending laboratory facilities and technical support. The research work was supported by CSIRJunior Research Fellowship, Government of India to Urfan Mohammad.

Conflicts of Interest: The authors declare no conflict of interest.

\section{References}

1. Hou, D.; Yousaf, L.; Xue, Y.; Hu, J.; Wu, J.; Hu, X.; Feng, N.; Shen, Q. Mung bean (Vigna radiata L.): Bioactive polyphenols, polysaccharides, peptides, and health benefits. Nutrients 2019, 11, 1238. [CrossRef]

2. Sanaei, F.; Amin, M.M.; Alavijeh, Z.P.; Esfahani, R.A.; Sadeghi, M.; Bandarrig, N.S.; Fatehizadeh, A.; Taheri, E.; Rezakazemi, M. Health risk assessment of potentially toxic elements intake via food crops consumption: Monte Carlo simulation-based probabilistic and heavy metal pollution index. Environ. Sci. Pollut. Res. Int. 2020, 28, 1479-1490. [CrossRef]

3. Zheng, S.; Wang, Q.; Yuan, Y.; Sun, W. Human health risk assessment of heavy metals in soil and food crops in the Pearl River Delta urban agglomeration of China. Food Chem. 2020, 316, 126213. [CrossRef]

4. Shanying, H.E.; Xiaoe, Y.A.N.G.; Zhenli, H.E. Morphological and physiological responses of plants to cadmium toxicity: A review. Pedosphere 2017, 27, 421-438. 
5. Kubier, A.; Wilkin, R.T.; Pichler, T. Cadmium in soils and groundwater: A review. Appl. Geochem. 2019, 108, 104388. [CrossRef] [PubMed]

6. Zhao, F.J.; Huang, X.Y. Cadmium phytoremediation: Call rice CAL1. Mol. Plant 2018, 11, 640-642. [CrossRef] [PubMed]

7. Qin, S.; Liu, H.; Nie, Z.; Rengel, Z.; Gao, W.; Li, C.; Zhao, P. Toxicity of cadmium and its competition with mineral nutrients for uptake by plants: A review. Pedosphere 2020, 30, 168-180. [CrossRef]

8. Azhar, M.; ur Rehman, M.Z.; Ali, S.; Qayyum, M.F.; Naeem, A.; Ayub, M.A.; HaqMAu Iqbal, A.; Rizwan, M. Comparative effectiveness of different biochars and conventional organic materials on growth, photosynthesis and cadmium accumulation in cereals. Chemosphere 2019, 227, 72-81. [CrossRef]

9. Calero-Muñoz, N.; Exposito-Rodriguez, M.; Collado-Arenal, A.M.; Rodríguez-Serrano, M.; Laureano-Marín, A.M.; Santamaría, M.E.; Gotor, C.; Díaz, I.; Mullineaux, P.M.; Romero-Puertas, M.C.; et al. Cadmium induces reactive oxygen species-dependent pexophagy in Arabidopsis leaves. Plant Cell Environ. 2019, 42, 2696-2714. [CrossRef]

10. Bangar, P.; Chaudhury, A.; Tiwari, B.; Kumar, S.; Kumari, R.; Bhat, K.V. Morphophysiological and biochemical response of mungbean [Vigna radiata (L.) Wilczek] varieties at different developmental stages under drought stress. Turk. J. Biol. 2019, 43, 58-69. [CrossRef]

11. Silambarasan, S.; Logeswari, P.; Cornejo, P.; Kannan, V.R. Role of plant growth-promoting rhizobacterial consortium in improving the Vigna radiata growth and alleviation of aluminum and drought stresses. Environ. Sci. Pollut. Res. Int. 2019, 26, 27647-27659. [CrossRef]

12. Sehrawat, N.; Yadav, M.; Sharma, A.K.; Kumar, V.; Bhat, K.V. Salt stress and mungbean [Vigna radiata (L.) Wilczek]: Effects, physiological perspective and management practices for alleviating salinity. Arch. Agron. Soil Sci. 2019, 65, 1287-1301. [CrossRef]

13. Ranjan, J.; Mandal, T.; Mandal, D.D. Mechanistic insight for DBP induced growth inhibition in Vigna radiata via oxidative stress and DNA damage. Chemosphere 2021, 263, 128062. [CrossRef]

14. Pandey, A.K.; Burlakoti, R.R.; Kenyon, L.; Nair, R.M. Perspectives and challenges for sustainable management of fungal diseases of mungbean [Vigna radiata (L.) R. Wilczek var. radiata]: A Review. Front. Environ. Sci. 2018, 6, 53. [CrossRef]

15. Ghani, A. Effect of cadmium toxicity on the growth and yield components of mungbean [Vigna radiata (L.) Wilczek]. World Appl. Sci. J. 2010, 8, 26-29.

16. Wu, Z.; Xu, S.; Shi, H.; Zhao, P.; Liu, X.; Li, F.; Wang, F. Comparison of foliar silicon and selenium on cadmium absorption, compartmentation, translocation and the antioxidant system in Chinese flowering cabbage. Ecotoxicol. Environ. Saf. 2018, 166, 157-164. [CrossRef]

17. Shekari, L.; Aroiee, H.; Mirshekari, A. Protective role of selenium on cucumber (Cucumis sativus L.) exposed to cadmium and lead stress during reproductive stage role of selenium on heavy metals stress. J. Plant Nutr. 2019, 42, 529-542. [CrossRef]

18. Ovečka, M.; Takáč, T. Managing heavy metal toxicity stress in plants: Biological and biotechnological tools. Biotechnol. Adv. 2014, 32, 73-86. [CrossRef]

19. Tiwari, S.; Lata, C. Heavy metal stress, signaling, and tolerance due to plant-associated microbes: An overview. Front. Plant Sci. 2018, 9, 452. [CrossRef]

20. Ai, T.N.; Naing, A.H.; Yun, B.W.; Lim, S.H.; Kim, C.K. Overexpression of RsMYB1 enhances anthocyanin accumulation and heavy metal stress tolerance in transgenic petunia. Front. Plant Sci. 2018, 9, 1388. [CrossRef]

21. Belykh, E.S.; Maystrenko, T.A.; Velegzhaninov, I.O. Recent trends in enhancing the resistance of cultivated plants to heavy metal stress by transgenesis and transcriptional programming. Mol. Biotechnol. 2019, 61, 725-741. [CrossRef]

22. Nguyen, T.Q.; Sesin, V.; Kisiala, A.; Emery, R.N. Phytohormonal Roles in Plant Responses to Heavy Metal Stress: Implications for Using Macrophytes in Phytoremediation of Aquatic Ecosystems. Environ. Toxicol. Chem. 2021, 40, 7-22. [CrossRef]

23. Shukla, M.; Al-Busaidi, K.T.; Trivedi, M.; Tiwari, R.K. Status of research, regulations and challenges for genetically modified crops in India. GM Crops Food 2018, 9, 173-188. [CrossRef]

24. Karky, R.B.; Perry, M. Disharmonization in the regulation of transgenic plants in Europe. Biotechnol. Law Rep. 2019, 38, 350-375. [CrossRef]

25. Mohite, B.V.; Koli, S.H.; Narkhede, C.P.; Patil, S.N.; Patil, S.V. Prospective of microbial exopolysaccharide for heavy metal exclusion. Appl. Biochem. Biotechnol. 2017, 183, 582-600. [CrossRef]

26. Sytar, O.; Kumari, P.; Yadav, S.; Brestic, M.; Rastogi, A. Phytohormone priming: Regulator for heavy metal stress in plants. J. Plant Growth Regul. 2019, 38, 739-752. [CrossRef]

27. Haq, S.; Bhatti, A.A.; Dar, Z.A.; Bhat, S.A. Phytoremediation of heavy metals: An eco-friendly and sustainable approach, In Bioremediation and Biotechnology; Springer: Cham, Switzerland, 2020; pp. 215-231.

28. Hasan, S.; Sehar, Z.; Khan, N.A. Gibberellic Acid and Sulfur-Mediated Reversal of Cadmium-Inhibited Photosynthetic Performance in Mungbean (Vigna radiata L.) Involves Nitric Oxide. J. Plant Growth Regul. 2020, 39, 1605-1615. [CrossRef]

29. Asgher, M.; Khan MI, R.; Anjum, N.A.; Khan, N.A. Minimising toxicity of cadmium in plants—role of plant growth regulators. Protoplasma 2015, 252, 399-413. [CrossRef]

30. Mohan, R.; Kaur, T.; Bhat, H.A.; Khajuria, M.; Pal, S.; Vyas, D. Paclobutrazol induces photochemical efficiency in mulberry (Morus alba L.) under water stress and affects leaf yield without influencing biotic interactions. J. Plant Growth Regul. 2019, 39, 205-215. [CrossRef]

31. Urfan, M.; Hakla, H.R.; Sharma, S.; Sharma, M.; Khajuria, M.; Vyas, D.; Satbhai, S.B.; Pal, S. Exploring phenotyping plasticity for improving deficit irrigation and growth performance in maize. bioRxiv 2020. [CrossRef] 
32. Bakkali, K.; Martos, N.R.; Souhail, B.; Ballesteros, E. Characterization of trace metals in vegetables by graphite furnace atomic absorption spectrometry after closed vessel microwave digestion. Food Chem. 2009, 116, 590-594. [CrossRef]

33. Lichtenthaler, H.K. Chlorophylls and carotenoids: Pigments of photosynthetic biomembranes. Methods Enzymol. 1987, 148, 350-382.

34. Miller, G.L. Modified DNS method for reducing sugars. Anal. Chem. 1959, 31, 426-428. [CrossRef]

35. Pal, S.; Zhao, J.; Khan, A.; Yadav, N.S.; Batushansky, A.; Barak, S.; Rewald, B.; Fait, A.; Lazarovitch, N.; Rachmilevitch, S. Paclobutrazol induces tolerance in tomato to deficit irrigation through diversified effects on plant morphology, physiology and metabolism. Sci. Rep. 2016, 6, 39321. [CrossRef] [PubMed]

36. Kandeler, E.; Gerber, H. Short-term assay of soil urease activity using colorimetric determination of ammonium. Biol. Fertil. Soils. 1988, 6, 68-72. [CrossRef]

37. Choudhary, S.P.; Oral, H.V.; Bhardwaj, R.; Yu, J.Q.; Tran LS, P. Interaction of brassinosteroids and polyamines enhances copper stress tolerance in Raphanus sativus. J. Exper. Bot. 2012, 63, 5659-5675. [CrossRef]

38. Haider, M.U.; Hussain, M.; Farooq, M.; Nawaz, A. Optimizing zinc seed priming for improving the growth, yield and grain biofortification of mungbean (Vigna radiata (L.) Wilczek). J. Plant Nutr. 2020, 43, 1438-1446. [CrossRef]

39. Muneer, S.; Jeong, B.R.; Kim, T.H.; Lee, J.H.; Soundara rajan, P. Transcriptional and physiological changes in relation to Fe uptake under conditions of Fe-deficiency and Cd-toxicity in roots of Vigna radiate L. J. Plant Res. 2014, 127, 731-742. [CrossRef] [PubMed]

40. Hu, B.; Xue, J.; Zhou, Y.; Shao, S.; Fu, Z.; Li, Y.; Chen, S.; Qi, L.; Shi, Z. Modelling bioaccumulation of heavy metals in soil-crop ecosystems and identifying its controlling factors using machine learning. Environ. Pollut. 2020, 262, 114308. [CrossRef]

41. Lu, Z.; Zhang, Z.; Su, Y.; Liu, C.; Shi, G. Cultivar variation in morphological response of peanut roots to cadmium stress and its relation to cadmium accumulation. Ecotoxicol. Environ. Saf. 2013, 91, 147-155. [CrossRef]

42. Mohammadzadeh, A.; Tavakoli, M.; Motesharezadeh, B.; Chaichi, M.R. Effects of plant growth-promoting bacteria on the phytoremediation of cadmium-contaminated soil by sunflower. Arch. Agron. Soil Sci. 2017, 63, 807-816. [CrossRef]

43. Manoj, K.; Sinhal, V.K.; Alok, S.; Singh, V.P. Zinc alleviates cadmium induced toxicity in Vigna radiate (L.) Wilczek. J. Phytol. 2011, $3,43-46$.

44. Meng, H.; Hua, S.; Shamsi, I.H.; Jilani, G.; Li, Y.; Jiang, L. Cadmium-induced stress on the seed germination and seedling growth of Brassica napus L. and its alleviation through exogenous plant growth regulators. Plant Growth Regul. 2009, 58, 47-59. [CrossRef]

45. Ghani, A.; Wahid, A. Varietal differences for cadmium-induced seedling mortality and foliar-toxicity symptoms in mungbean (Vigna radiata). Int. J. Agric. Biol. 2007, 9, 555-558.

46. Xu, Q.; Krishnan, S.; Merewitz, E.; Xu, J.; Huang, B. Gibberellin-regulation and genetic variations in leaf elongation for tall fescue in association with differential gene expression controlling cell expansion. Sci. Rep. 2016, 6, 30258. [CrossRef] [PubMed]

47. Singh, G.S.; Tuteja, N. Cadmium stress tolerance in crop plants: Probing the role of sulfur. Plant Signal Behav. 2011, 6, 215-222.

48. Rizvi, A.; Khan, M.S. Biotoxic impact of heavy metals on growth, oxidative stress and morphological changes in root structure of wheat (Triticum aestivum L.) and stress alleviation by Pseudomonas aeruginosa strain CPSB1. Chemosphere 2017, 185, 942-952. [CrossRef] [PubMed]

49. Alyemeni, M.N.; Hayat, Q.; Hayat, S.; Faizan, M.; Faraz, A. Exogenous proline application enhances the efficiency of nitrogen fixation and assimilation in chickpea plants exposed to cadmium. Legum. Res. 2016, 39, 2. [CrossRef]

50. Balestrasse, K.B.; Gallego, S.M.; Tomaro, M.L. Cadmium-induced senescence in nodules of soybean (Glycine max L.) plants. Plant Soil. 2004, 262, 373-381. [CrossRef]

51. Rai, R.; Agrawal, M.; Agrawal, S.B. Impact of heavy metals on physiological processes of plants: With special reference to photosynthetic system. In Plant Responses to Xenobiotics; Springer: Singapore, 2016; pp. 127-140.

52. Ouzounidou, G.; Ilias, I. Hormone-induced protection of sunflower photosynthetic apparatus against copper toxicity. Biol. Plant. 2005, 49, 223. [CrossRef]

53. Vijendra, P.D.; Huchappa, K.M.; Lingappa, R.; Basappa, G.; Jayanna, S.G.; Kumar, V. Physiological and biochemical changes in moth bean (Vigna aconitifolia L.) under cadmium stress. J. Bot. 2016. [CrossRef]

54. Cai, B.; Wang, H.; Liu, T.; Zhuang, W.; Wang, Z.; Qu, S.; Qin, Y. Effects of gibberellins A4 on budbreak, antioxidant enzymes activity and proline content of flower buds in sweet cherry (Prunus avium). Acta Physiol. Plant. 2019, 41, 1-9. [CrossRef]

55. Tian, S.F.; Wang, Y.; Du, G.; Li, Y.X. Changes in contents and antioxidant activity of phenolic compounds during gibberellininduced development in Vitis vinifera L. 'Muscat'. Acta Physiol. Plant. 2011, 33, 2467-2475. [CrossRef]

56. Jinlong, Y.; Quan, G.; Ding, C. Effects of the combined pollution of lead and cadmium on soil urease activity and nitrification. Procedia Environ. Sci. 2013, 18, 78-83. 